Article

\title{
Explorative Screening of Bioactivities Generated by Plant-Based Proteins after In Vitro Static Gastrointestinal Digestion
}

\author{
Camille Dugardin ${ }^{1}$, Benoit Cudennec ${ }^{1, *}\left(\mathbb{D}\right.$, Mélissa Tourret ${ }^{1}$, Juliette Caron ${ }^{2}$, \\ Laetitia Guérin-Deremaux ${ }^{2}$, Josette Behra-Miellet ${ }^{1}$, Catherine Lefranc-Millot ${ }^{3}$ \\ and Rozenn Ravallec ${ }^{1, *}$ \\ 1 UMR-T 1158, BioEcoAgro, University of Lille, F-59000 Lille, France; camille.dugardin@univ-lille.fr (C.D.); \\ melissa.tourret@univ-lille.fr (M.T.); josette.behra@univ-lille.fr (J.B.-M.) \\ 2 Nutrition and Health Research \& Development, Roquette, F-62136 Lestrem, France; \\ juliette.caron@roquette.com (J.C.); laetitia.guerin-deremaux@roquette.com (L.G.-D.) \\ 3 Nutrition and Health Research \& Development, Roquette, F-59110 La Madeleine, France; \\ catherine.lefranc-millot@roquette.com \\ * Correspondence: benoit.cudennec@univ-lille.fr (B.C.); rozenn.ravallec@univ-lille.fr (R.R.)
}

Received: 13 October 2020; Accepted: 2 December 2020; Published: 5 December 2020

check for updates

\begin{abstract}
The gastrointestinal digestion of food proteins can generate peptides with a wide range of biological activities. In this study, we screened various potential bioactivities generated by plant-based proteins. Whey protein as an animal protein reference, five grades of pea protein, two grades of wheat protein, and potato, fava bean, and oat proteins were submitted to in vitro SGID. They were then tested in vitro for several bioactivities including measures on: (1) energy homeostasis through their ability to modulate intestinal hormone secretion, to inhibit DPP-IV activity, and to interact with opioid receptors; (2) anti-hypertensive properties through their ability to inhibit ACE activity; (3) anti-inflammatory properties in Caco-2 cells; (4) antioxidant properties through their ability to inhibit production of reactive oxygen species (ROS). Protein intestinal digestions were able to stimulate intestinal hormone secretion by enteroendocrine cells, to inhibit DPP-IV and ACE activities, to bind opioid receptors, and surprisingly, to decrease production of ROS. Neither pro- nor anti-inflammatory effects have been highlighted and some proteins lost their pro-inflammatory potential after digestion. The best candidates were pea, potato, and fava bean proteins.
\end{abstract}

Keywords: plant-based protein digestion; biological activity; CCK; GLP-1; DPP-IV; opioid receptor; ACE; inflammation; IL-8; ROS production

\section{Introduction}

According to the Food and Agriculture Organization (FAO), current trends predict a constant increase in worldwide population, reaching nearly 10 billion people in 2050. Moreover, the international recommended dietary allowance for protein is currently $0.8 \mathrm{~g}$ per $\mathrm{kg}$ of body weight [1]. As a consequence, global protein demand should increase to meet the nutritional needs of the growing population. Additionally, since 1961, worldwide protein consumption has increased by about 20 g per day and per person. In this context, it becomes essential to better characterize dietary proteins and to diversify their origins. Whereas the high proportion of animal-protein consumption in developed countries raises environmental concerns, relying on intensive livestock farming [2], plant-based proteins appear as a more sustainable alternative. Indeed, the environmental footprint of plant-based proteins is lower due to less greenhouse gas emission and water consumption, leading to a better protein delivery efficiency [3]. Moreover, the proportion of the population becoming vegan, vegetarian, 
or flexitarian is increasing, promoted by ecological and health concerns but also the ethical treatment of animals [4]. In parallel, according to the World Health Organization, more than 1.9 billion adults were overweight in 2016. Among them, more than 600 million were obese $(13 \%$ of the worldwide adult population). Obesity is a major risk factor for the development of type 2 diabetes mellitus (T2DM), which is a metabolic disorder characterized by prolonged hyperglycemia, leading to complications like hypertension and associated cardiovascular diseases.

Beyond their nutritional role as the source of amino acids for protein synthesis, dietary proteins are known to be involved in a wide range of biological functions [5], particularly through the action of peptides generated during their digestion in the gastrointestinal tract. Indeed, during this enzymatic process, dietary proteins are first partially hydrolyzed by pepsin in the stomach, then by a cocktail of proteases (trypsin, chymotrypsin, carboxypeptidases) in the small intestine, and finally, by peptidases at the brush border membrane. This generates amino acids and bioactive peptides present in the intestinal lumen whose size, sequence, and structure vary and which modulate several physiological processes by acting locally and/or systemically [6-8]. Several health-related effects have been described for bioactive peptides coming from different sources, using in vitro tests or animal and human trials $[9,10]$. For instance, it has been shown that peptides generated by dietary protein digestion could play a beneficial role in the context of obesity and metabolic disorders through the peripheral regulation of food intake [11]. Peripheral regulation of short-term food intake by proteins involves the stimulation of intestinal hormone secretion following the recognition of nutrients, such as digested protein-derived peptides, at the apical level of the enteroendocrine cells. This intestinal "sensing" leads to the secretion of anorexigenic peptide hormones such as cholecystokinin (CCK) and glucagon-like peptide 1 (GLP-1) that act as peripheral signals leading to the end of food intake [12,13]. GLP-1 plays also a crucial role in glucose metabolism by its role as incretin [14], which is drastically reduced by the dipeptidyl peptidase-4 (DPP-IV) enzymatic action, removing dipeptides from their N-terminal side [15]. Hence, DPP-IV inhibitors are nowadays considered as an advanced class of agents for T2DM management [16] and in recent years, numerous studies evidenced "natural" DPP-IV inhibitory peptides from digested dietary proteins [17]. Food-derived peptides may also bind peripheral opioid receptors in the portal vein and indirectly induce satiety via gluconeogenesis $[18,19]$. Dietary protein-derived peptides are also promising in the context of hypertension and associated cardiovascular risk, particularly by their ability to inhibit the Angiotensin Converting Enzyme (ACE), a dipeptidyl carboxypeptidase which plays an important role in the regulation of blood pressure by cleaving angiotensin I to induce vasoconstriction [20]. Several in vitro and animal trials had also evidenced the attractive potential of food-derived peptides in the management of human inflammatory bowel disease (IBD) via their anti-inflammatory effect and antioxidant activities [21]. However, data describing the relationship existing between the source and quality of protein and their biological activities are limited and inconsistent. Moreover, studies comparing numerous protein sources are lacking.

The purpose of the present study was thus to investigate in vitro the ability of 10 dietary plant-based proteins to modulate (1) food intake and glucose homeostasis through CCK and GLP-1 secretion, DPP-IV activity, and opioid receptor binding; (2) blood pressure through ACE activity; (3) inflammation through interleukin-8 (IL-8) secretion; (4) oxidative stress through reactive oxygen species (ROS) production. To do that, an in vitro simulated gastrointestinal digestion (SGID) was firstly performed in order to reach study conditions closer to the physiological ones but also to highlight and compare the effect of non-digested and digested dietary proteins on these biological activities. The protein sources have been chosen for two reasons. On the one hand, some of these sources are rich in proteins (e.g., pea) and thus, interesting for human consumption. On the other hand, some of these sources generate a lot of protein by-products (e.g., potato), which could be valorized. 


\section{Materials and Methods}

\subsection{Protein Samples}

Ten plant-based protein samples were provided by Roquette (Table 1):

- $\quad$ Four grades of pea protein (PeaP1, PeaP2, PeaP3, and PeaP4);

- Hydrolyzed pea protein (HPeaP);

- $\quad$ Two grades of wheat protein (WP1 and WP2);

- $\quad$ Potato protein (PP);

- $\quad$ Fava bean protein (FBP);

- $\quad$ Oat protein (OP).

Table 1. Description and characterization of the 11 protein samples studied.

\begin{tabular}{cccc}
\hline Name & Description & \% Dry Matter & \% Protein \\
\hline PeaP1 & Pea protein-grade 1 & 93.0 & 79.1 \\
PeaP2 & Pea protein-grade 2 & 95.2 & 79.7 \\
PeaP3 & Pea protein-grade 3 & 94.4 & 80.8 \\
PeaP4 & Pea protein-grade 4 & 95.6 & 81.5 \\
HPeaP & Hydrolyzed pea protein & 94.6 & 78.3 \\
WP1 & Wheat protein-grade 1 & 94.8 & 83.7 \\
WP2 & Wheat protein-grade 2 & 93.2 & 93.2 \\
PP & Potato protein & 93.8 & 79.1 \\
FBP & Fava bean protein & 96.0 & 89.8 \\
OP & Oat protein & 96.0 & 88.3 \\
WhP & Whey protein & 95.0 & 85.5 \\
\hline
\end{tabular}

PeaP1-PeaP4 (4 grades of pea protein), HPeaP (hydrolyzed pea protein), WP1-WP2 (2 grades of wheat protein), PP (potato protein), FBP (fava bean protein), OP (oat protein) and WhP (Whey protein).

We performed two sets of analysis: the first one including PeaP1, HPeaP, WP1, WP2, and PP; the second one including PeaP2, PeaP3, PeaP4, FBP, and OP. Whey protein (WhP) was used as an animal protein reference and common control in each set of analysis.

\subsection{Materials}

Porcine pepsin (EC 3.4.23.1, from porcine gastric mucosa, $3850 \mathrm{U} \mathrm{mg}^{-1}$ protein), pancreatin from porcine pancreas $\left(4 \times\right.$ USP specifications (5.46 $\mathrm{U} \mathrm{mg}^{-1}$ based on trypsin activity), EC 232-468-9), Dipeptidyl Peptidase IV (DPP-IV from porcine kidney, EC 3.4.14.5, $\geq 10 \mathrm{U} \mathrm{mg}^{-1}$ protein), Gly-Pro-p-nitroanilide hydrochloride, Angiotensin Converting Enzyme (ACE from rabbit lung, EC 3.4.15.1), and all other reagents were purchased from Sigma-Aldrich (Sigma-Aldrich, Steinheim, Germany). The Active Glucagon-Like Peptide RIA kit (Cat.\# GLP1A-35HK) was purchased from Merck Millipore (Merck-Millipore, Darmstadt, Germany). The Gastrin/CCK kit was purchased from CisBio (CisBio, Saclay, France). Human IL-8/CXCL8 Quantikine ELISA Kit (D8000C) was purchased from R\&D Systems (R\&D Sytems, Minneapolis, MN, USA).

\subsection{In Vitro Simulated Gastrointestinal Digestion (SGID)}

In vitro simulated gastrointestinal digestion (SGID) was performed as previously described [22]. The first three steps of digestion were simulated (mouth, stomach, and duodenum) and three fluids were prepared to mimic the physiological conditions of each step. The composition of each fluid was described in Table 2 and the $\mathrm{pH}$ of the solutions was adjusted to physiologically relevant values using $\mathrm{NaOH}(5 \mathrm{M})$ and $\mathrm{HCl}(5 \mathrm{M})$ solutions. The whole digestion process was performed in a $200 \mathrm{~mL}$ reactor controlled at $37^{\circ} \mathrm{C}$ under constant stirring with a magnetic stirrer over $240 \mathrm{~min}$. Then, $2 \mathrm{~g}$ of native protein sample (dry weight) was added to the reactor and solubilized in $16 \mathrm{~mL}$ salivary fluids 
at pH 6.8 (125 mg mL $\mathrm{m}^{-1}$ dry matter). After $5 \mathrm{~min}$, sampling of $4 \mathrm{~mL}$ was performed at the end of the salivary step (salivary sample). Next, $24 \mathrm{~mL}$ of gastric fluids containing pepsin were added after saliva sampling at an Enzyme: Substrate (E:S) ratio of 1:40 (w/w) and the $\mathrm{pH}$ of the solution was adjusted (2.5-3.0). After $2 \mathrm{~h}$, sampling of $16 \mathrm{~mL}$ was performed at the end of the gastric step (gastric digestion- $41.67 \mathrm{mg} \mathrm{mL}^{-1}$ dry matter). A total of $36 \mathrm{~mL}$ of intestinal fluids ( $24 \mathrm{~mL}$ of duodenal juice and $12 \mathrm{~mL}$ of bile juice) containing pancreatin at a E:S ratio of 1:50 (w/w) and $4 \mathrm{~mL}$ of $1 \mathrm{M} \mathrm{NaHCO}_{3}$ were then added to the batch and the $\mathrm{pH}$ of the solution was adjusted to 7 . Intestinal digestion was carried out again over $2 \mathrm{~h}$ and sampling of $60 \mathrm{~mL}$ was performed at the end of the intestinal step (intestinal digestion). Intestinal digestion concentration reached $13.89 \mathrm{mg} \mathrm{mL}^{-1}$ dry matter. Once heated at $95{ }^{\circ} \mathrm{C}$ for $10 \mathrm{~min}$ to assure enzyme denaturation without peptide damage, all samples were centrifuged at $13,400 \times g$ for $10 \mathrm{~min}$ at room temperature. Supernatants were collected and frozen for further analysis.

Table 2. Chemical composition, protease concentration, and $\mathrm{pH}$ used for the different compartments of the in vitro simulated gastrointestinal digestion (SGID).

\begin{tabular}{|c|c|c|c|c|}
\hline Characteristics & Saliva & Gastric Juice & Duodenal Juice & Bile Juice \\
\hline \multirow{7}{*}{$\begin{array}{l}\text { Chemical } \\
\text { Composition }\end{array}$} & $\mathrm{KCl}(12 \mathrm{mM})$ & $\mathrm{KCl}(11 \mathrm{mM})$ & $\mathrm{KCl}(7.6 \mathrm{mM})$ & $\mathrm{KCl}(5 \mathrm{mM})$ \\
\hline & KSCN (2 mM) & $\mathrm{NaH}_{2} \mathrm{PO}_{4}(2.2 \mathrm{mM})$ & $\mathrm{KH}_{2} \mathrm{PO}_{4}(0.6 \mathrm{mM})$ & $\mathrm{NaCl}(90 \mathrm{mM})$ \\
\hline & $\mathrm{NaH}_{2} \mathrm{PO}_{4}(7.4 \mathrm{mM})$ & $\mathrm{NH}_{4} \mathrm{Cl}(5.7 \mathrm{mM})$ & $\mathrm{NaCl}(120 \mathrm{mM})$ & $\mathrm{NaHCO}_{3}(69 \mathrm{mM})$ \\
\hline & $\mathrm{Na}_{2} \mathrm{SO} 4(4 \mathrm{mM})$ & $\mathrm{NaCl}(47 \mathrm{mM})$ & $\mathrm{NaHCO}_{3}(40 \mathrm{mM})$ & $\mathrm{HCl}(1.5 \mathrm{mM})$ \\
\hline & $\mathrm{NaCl}(5 \mathrm{mM})$ & $\mathrm{HCl}(6.5 \mathrm{mM})$ & $\mathrm{HCl}(1.8 \mathrm{mM})$ & $\mathrm{CO}\left(\mathrm{NH}_{2}\right)_{2}(4 \mathrm{mM})$ \\
\hline & NaHCO3 (20 mM) & $\mathrm{CaCl}_{2}(2.7 \mathrm{mM})$ & $\mathrm{MgCl}_{2}(0.5 \mathrm{mM})$ & \\
\hline & $\mathrm{CO}\left(\mathrm{NH}_{2}\right)_{2}(3.3 \mathrm{mM})$ & $\mathrm{CO}\left(\mathrm{NH}_{2}\right)_{2}(1.4 \mathrm{mM})$ & $\mathrm{CO}\left(\mathrm{NH}_{2}\right)_{2}(1.7 \mathrm{mM})$ & \\
\hline Proteases & & Pepsin 1/40 (w/w) & Pancreatin $1 / 50(w / w)$ & \\
\hline $\mathrm{pH}$ & $6.8 \pm 0.2$ & $1.3 \pm 0.2$ & $8.1 \pm 0.2$ & $8.2 \pm 0.2$ \\
\hline
\end{tabular}

Two sets of analysis were performed: the first one including PeaP1, HPeaP, WP1, WP2, PP, and WhP; the second one PeaP2, PeaP3, PeaP4, FBP, OP, and WhP. SGID was achieved in triplicates on each of the 10 protein samples provided by Roquette. As the reproducibility was demonstrated, SGID on the animal protein reference $\mathrm{WhP}$ was performed in triplicate for the first set of analysis and only once for the second set of analysis.

A blank SGID (without any protein sample but with digestive enzymes) was also achieved in order to exclude any activity due to enzyme autolysis in all further analysis.

\subsection{Solubility Tests}

The solubility degree of each protein sample was evaluated at each step of the SGID process (Table 3). To do that, dry matter percentage (\% DM) of each sample before and after centrifugation at $13,400 \times g$ for $10 \mathrm{~min}$ at room temperature was assessed using a desiccator. The solubility degree was calculated by the ratio between \% DM after centrifugation and \% DM before centrifugation. The solubility degree was then applied to theoretical dry matter concentration to predict the real dry matter concentration of each protein sample at each step of the SGID process. All further analyses were based on this predicted dry matter concentration.

\subsection{Size Exclusion Chromatography}

To evaluate SGID triplicate reproducibility, size exclusion chromatography was used to analyze and compare the peptide molecular weight distribution of the digested samples (intestinal digestion). Separation was performed at room temperature using a Superdex Peptide 10/300 GL column under isocratic elution at a flow rate of $0.5 \mathrm{~mL} \mathrm{~min}^{-1}$ with a $30 \%$ acetonitrile, $0.1 \%$ TFA solvent. Absorbance was monitored at $214 \mathrm{~nm}$ using an AKTA purifier protein purification system (GE Healthcare, Amersham, UK). The column was calibrated using standard peptides (Albumin, $60 \mathrm{kDa}$; Cytochrome C, 12,400 Da; Aprotinin, 6500 Da; Vitamin B12, 1355 Da; Glutathione, 307 Da). The relationship between the Log 
of molecular weight standard peptides and the elution volume was used to perform the molecular weight profiles of the samples.

Table 3. Solubility degree (\%) of the 11 protein samples, at each step of the SGID.

\begin{tabular}{cccc}
\hline Name & Salivary Sample & Gastric Digestion & Intestinal Digestion \\
\hline PeaP1 & 20.53 & 61.65 & 85.97 \\
PeaP2 & 43.55 & 58.67 & 83.94 \\
PeaP3 & 47.27 & 69.47 & 86.32 \\
PeaP4 & 100.00 & 82.81 & 86.96 \\
HPeaP & 81.16 & 82.39 & 95.61 \\
WP1 & 63.33 & 75.56 & 93.40 \\
WP2 & 90.08 & 100.00 & 100.00 \\
PP & 9.13 & 51.79 & 69.77 \\
FBP & 39.41 & 56.72 & 90.34 \\
OP & 18.33 & 69.35 & 83.58 \\
WhP & 91.97 & 69.97 & 100.00 \\
\hline
\end{tabular}

PeaP1-PeaP4 (4 grades of pea protein), HPeaP (hydrolyzed pea protein), WP1-WP2 (2 grades of wheat protein), PP (potato protein), FBP (fava bean protein), OP (oat protein) and WhP (Whey protein).

\subsection{Bioactivity Tests}

All further analyses were performed on each protein sample, at least before and after SGID.

\subsubsection{CCK and GLP-1 Secretion Study}

The CCK and GLP-1 secretion study was performed as previously described [22]. STC-1 cells were seeded into 24 -well culture plates at a density of $30 \times 10^{3}$ per well and allowed to reach $60-80 \%$ confluence. Then, cells were washed and incubated with 3 different concentrations $(0.2 \%, 0.5 \%$, $1 \% w / v$; dose response in triplicates) of protein samples before (salivary sample) and after SGID (intestinal digestion). Dilutions were made in incubation buffer $(4.5 \mathrm{mM} \mathrm{KCl}, 1.2 \mathrm{mM} \mathrm{CaCl}, 1.2 \mathrm{mM}$ $\mathrm{MgCl}_{2}, 140 \mathrm{mM} \mathrm{NaCl}$, and $20 \mathrm{mM}$ Hepes-Tris, $\mathrm{pH}$ 7.4). Control wells contained only incubation buffer. After $2 \mathrm{~h}$ incubation at $37^{\circ} \mathrm{C}$ in $5 \% \mathrm{CO}_{2}$ atmosphere, supernatants were collected on ice and centrifuged $(2000 \times g$ for $7 \mathrm{~min})$. The supernatants were frozen and stored at $-20^{\circ} \mathrm{C}$ for further hormone concentration determination. Secreted CCK and GLP-1 concentration (pM) in culture media of STC-1 cells was assayed using commercial RIA kits: CCK (CisBio, Saclay, France) and GLP-1 (Merck-Millipore, Darmstadt, Germany).

\subsubsection{DPP-IV Inhibition Assay}

The DPP-IV inhibitory activity of the protein samples before (salivary sample), during (gastric digestion), and after SGID (intestinal digestion) was assayed according to the method described by Lacroix et al. [23] with some modifications. Concisely, $25 \mu \mathrm{L}$ of each sample at concentrations ranging from 1.21 to $13.89 \mathrm{mg} \mathrm{mL}^{-1}$ (dose response of 4 concentrations in triplicates) were pre-incubated with $75 \mu \mathrm{L}$ of Tris/ $\mathrm{HCl}$ buffer $(100 \mathrm{mM}, \mathrm{pH} 8.0)$ and $25 \mu \mathrm{L}$ of DPP-IV $\left(0.018 \mathrm{U} \mathrm{mL}^{-1}\right)$ at $37^{\circ} \mathrm{C}$ for $5 \mathrm{~min}$ in a 96-well plate. For control purposes, the sample was replaced with Tris/HCl buffer $(100 \mathrm{mM}$, $\mathrm{pH}$ 8.0). Then, the reaction was initiated by the addition of $50 \mu \mathrm{L}$ of Gly-Pro-p-nitroanilide $(1 \mathrm{mM})$. All the samples and reagents were diluted in Tris/ $\mathrm{HCl}$ buffer. The plate was then incubated at $37^{\circ} \mathrm{C}$ for $1 \mathrm{~h}$, and the absorbance of the released p-nitroanilide at $405 \mathrm{~nm}$ at $2 \mathrm{~min}$ intervals assayed with a microplate reader (ELX808, Biotek, Winoosky, VT, USA). The concentration of the sample required to obtain 50\% inhibition of the DPP-IV activity $\left(\mathrm{IC}_{50}\right)$ was determined by plotting the \% DPP-IV inhibition as a function of the sample's final concentration natural logarithm. $\mathrm{IC}_{50}$ were expressed in $\mathrm{mg} \mathrm{mL}^{-1}$ dry matter. 


\subsubsection{Opioid Receptor Binding Assay}

The potential binding on opioid receptors of the samples before (salivary sample) and after SGID (intestinal digestion) was assessed in a radiobinding competition test with ${ }^{3} \mathrm{H}$-naloxone as the tritiated specific ligand on rat brain membrane preparation, described by Garreau et al. [24] with some modifications. Briefly, rat brains were homogenized in a buffer $(50 \mathrm{mM}$ Tris- $\mathrm{HCl}, 240 \mathrm{mM}$ sucrose, $5 \mathrm{mM} \mathrm{MgCl}_{2}$, and $2 \mathrm{mM}$ EDTA) and centrifuged at $1000 \times g$ for $5 \mathrm{~min}$ at $4{ }^{\circ} \mathrm{C}$. Supernatants were then centrifuged at $30,000 \times g$ for $30 \mathrm{~min}$ at $4{ }^{\circ} \mathrm{C}$ and the resulting pellets were resolubilized in the homogenization buffer. A protein assay was performed with the Sigma QuantiPro BCA Assay Kit. Serial dilution of native protein samples (salivary sample) and their SGID products (intestinal digestion) ranging from 0.6 to $36 \mathrm{mg} \mathrm{mL}^{-1}$ (dose response of 6 concentrations) or naloxone as positive control were realized in $50 \mathrm{mM}$ Tris- $\mathrm{HCl}$ buffer $\mathrm{pH} 7.4$ supplemented with $2 \%$ bovine serum albumin and were incubated in $0.9 \mathrm{mg} \mathrm{mL}^{-1}$ of rat brain membrane preparation with the addition of protease inhibitors, bestatin $(10 \mu \mathrm{M})$ and thiorphan $(0.1 \mu \mathrm{M})$, and $1 \mathrm{nM}$ of ${ }^{3} \mathrm{H}$-naloxone for $30 \mathrm{~min}$ at $25^{\circ} \mathrm{C}$. Non-specific binding was determined by adding an excess of naloxone $(5 \mu \mathrm{M})$ instead of the sample or naloxone dilutions. All conditions were run in duplicates. At the end of the incubation, separation of bound and unbound samples was performed by vacuum filtration through glass microfiber GF/B filters. Filters were inserted into scintillation vials, $3 \mathrm{~mL}$ Optiphase HiSafe 2 scintillation liquid was added, and radioactivity was counted on a beta-counter (Hidex 300 SL, Sciencetec, Villebon-sur-Yvette, France). Non-specific binding was subtracted from all values and specific binding was expressed as percentage of total specific binding $(\mathrm{cpm})$. $\mathrm{ED}_{50}$ (effective dose 50\%) are determined by non-linear regression analysis. $\mathrm{ED}_{50}$ is the dose of sample that removes $50 \%$ of ${ }^{3} \mathrm{H}$-naloxone maximal binding to opioid receptors in order to replace it.

\subsubsection{ACE Inhibition Assay}

The ACE inhibitory activity of the different native protein samples (comparable to salivary sample) as compared to their SGID products (gastric and intestinal digestions) was assayed according to the protocol described by Sentandreu and Toldra [25]. Concisely, $50 \mu \mathrm{L}$ of diluted samples at concentrations ranging from 0.30 to $13.89 \mathrm{mg} \mathrm{mL}^{-1}$ (dose response of 4 concentrations in duplicates) were pre-incubated with $50 \mu \mathrm{L}$ of ACE working solution (50 mU mL ${ }^{-1}$ enzyme activity) in a 96-well plate. The plate was then carefully shaken for a few seconds and incubated at $37^{\circ} \mathrm{C}$ for $10 \mathrm{~min}$. The enzyme reaction was started by adding $200 \mu \mathrm{L}$ of fluorescent substrate working solution (o-aminobenzoylglycyl-p-nitro-L-phenylalanyl-L-proline Abz-Gly-Phe( $\mathrm{NO}_{2}$ )-Pro at $0.45 \mathrm{mM}$ ). The plate was again carefully shaken for a few seconds and incubated at $37^{\circ} \mathrm{C}$. Fluorescence was measured after $30 \mathrm{~min}$ at excitation wavelength $365 \mathrm{~nm}$ and emission wavelength $415 \mathrm{~nm}$ using a Xenius XC spectrofluorometer. The concentration of the sample required to obtain $50 \%$ inhibition of the ACE activity $\left(\mathrm{IC}_{50}\right)$ was determined by plotting the \% ACE inhibition as a function of the sample's final concentration natural logarithm. $\mathrm{IC}_{50}$ were expressed in $\mu \mathrm{g} \mathrm{mL} \mathrm{m}^{-1}$ dry matter.

\subsubsection{IL-8 Secretion Assay}

Caco-2 cells were seeded into 24-well culture plates at a density of $4 \times 10^{4}$ cells per well and allowed to reach confluence and differentiation ( 2 weeks). Differentiated Caco-2 cells were submitted or not during $24 \mathrm{~h}$ to inflammatory stimuli with LPS (lipopolysaccharides, $20 \mu \mathrm{g} \mathrm{mL}-1$, Sigma-Aldrich). Then, cells were incubated with 3 different concentrations $(0.1 \%, 0.25 \%, 0.5 \%(w / v)$; dose response in triplicates) of native protein samples (salivary sample) compared to their SGID products (intestinal digestion) diluted in incubation buffer (4.5 mM KCl, $1.2 \mathrm{mM} \mathrm{CaCl}, 1.2 \mathrm{mM} \mathrm{MgCl} 2,140 \mathrm{mM} \mathrm{NaCl}$, and $20 \mathrm{mM}$ Hepes-Tris, pH 7.4). Control wells contained only incubation buffer. After 24h incubation at $37^{\circ} \mathrm{C}$ in $5 \% \mathrm{CO}_{2}$ atmosphere, supernatants were collected on ice and centrifuged ( $2000 \times g$ for $7 \mathrm{~min}$ ). The supernatants were frozen and stored at $-20^{\circ} \mathrm{C}$ for further cytokine concentration determination. Secreted IL-8 in culture media of Caco-2 cells was evaluated using commercial ELISA kits. 


\subsubsection{Antioxidant Assays}

Superoxide Anion Assay

Concentration of $\mathrm{O}_{2}{ }^{-}$was estimated using an acellular method, adapted from that reported by Aruoma et al. [26]. Briefly, the superoxide anion $\left(7\right.$ to $\left.10 \mathrm{nmol} \mathrm{mL}^{-1}\right)$ was produced in Hank's HEPES buffer ( $\mathrm{pH} 7.42)$ using a xanthin $(0.1 \mathrm{mM})$-xanthin oxidase $\left(50 \mathrm{mU} \mathrm{mL}^{-1}\right)$ system. This $\mathrm{O}_{2}{ }^{-}$ quantity was then incubated with different quantities of native protein samples and their SGID products from 1.25 to $5 \mathrm{mg} \mathrm{mL}^{-1}$ (dose response of 3 concentrations in triplicates) for $15 \mathrm{~min}$ at $25{ }^{\circ} \mathrm{C}$ with equine ferricytochrome c (FerC) $0.017 \mathrm{mM}$. Controls without the sample and with only $\mathrm{O}_{2}{ }^{-}$were also incubated. FerC (orange) was reduced to ferricytochrome c (pink) by the remaining superoxide anion radicals and the absorbance was measured by spectrophotometry at $550 \mathrm{~nm}$. Concentrations of $\mathrm{O}_{2}{ }^{-}$ were determined thanks to the ferricytochrome c extinction coefficient $\left(21.1 \times 10^{3} \mathrm{~L} \mathrm{~mol}^{-1} \mathrm{~cm}^{-1}\right)$ and the Beer-Lambert law and were expressed in nmol. $\mathrm{mL}^{-1}$. The same experiments were also performed on the salivary sample and the intestinal digestion of blank SGID (SGID only with enzymes), which induce a decrease in $\mathrm{O}_{2}{ }^{-}$production. To avoid any interference, $\mathrm{IC}_{50}$ values for the 11 protein samples (salivary sample and intestinal digestion) were calculated taking into account the individual effects of the blank SGID samples.

\section{Hydrogen Peroxide Assay}

Concentration of $\mathrm{H}_{2} \mathrm{O}_{2}$ was estimated using an acellular method, adapted from that reported by Thurman et al. [27]. Briefly, about $10 \mathrm{nmol} \cdot \mathrm{mL}^{-1}$ of $\mathrm{H}_{2} \mathrm{O}_{2}$ was incubated with different quantities of native protein samples and their SGID products from 1.25 to $5 \mathrm{mg} \mathrm{mL}^{-1}$ (dose response of 3 concentrations in triplicates) for 15 min at room temperature in Hank's HEPES (HH) buffer ( $\mathrm{pH} 7.42$ ). Controls without $\mathrm{H}_{2} \mathrm{O}_{2}$ (replaced by $\mathrm{HH}$ ) were also incubated for each sample dilution. After adding $40 \mu \mathrm{L}$ of $1 \mathrm{~N} \mathrm{HNO}_{3}, 200 \mu \mathrm{L}$ of $10 \mathrm{M}$ Iron (II) ammonium sulfate, and $100 \mu \mathrm{L}$ of $2.5 \mathrm{M} \mathrm{KSCN}$ (potassium thiocyanate), the tubes were mixed and the absorbance, reflecting the ferric thiocyanate red complexes, was measured by spectrophotometry at $480 \mathrm{~nm}$. Concentrations of $\mathrm{H}_{2} \mathrm{O}_{2}$ in the samples were determined by using a standard curve ranging from 2.5 to $20 \mathrm{nmol} \cdot \mathrm{mL}^{-1}$. The same experiments were also performed on the salivary sample and the intestinal digestion of blank SGID (SGID only with enzymes) which induce a decrease in $\mathrm{H}_{2} \mathrm{O}_{2}$ production. To avoid any interference, $\mathrm{IC}_{50}$ values for the 11 protein samples (salivary sample and intestinal digestion) were calculated taking into account the individual effects of the blank SGID samples.

\section{Hydroxyl Radical Assay}

Concentration of $\mathrm{HO}$ was estimated using an acellular method, adapted from that reported by Halliwell et al. [28]. In this method, $\mathrm{HO}$ was produced from $\mathrm{H}_{2} \mathrm{O}_{2}\left(10\right.$ to $\left.13 \mathrm{nmol} \mathrm{mL}{ }^{-1}\right)$ in a $\mathrm{KH}_{2} \mathrm{PO}_{4}$ $20 \mathrm{mM}$ buffer ( $\mathrm{pH}$ 7.4) by the Fenton reaction, with EDTA-Fe ${ }^{2+}\left(\mathrm{FeCl}_{3} 100 \mu \mathrm{M}\right.$ and EDTA $\left.104 \mu \mathrm{M}\right)$ and ascorbic acid $(100 \mu \mathrm{M})$. HO was then incubated with different quantities of native protein samples and their SGID products from 1.25 to $5 \mathrm{mg} \mathrm{mL}^{-1}$ (dose response of 3 concentrations in triplicates) and deoxyribose $(3 \mathrm{mM})$ for $30 \mathrm{~min}$ at $37^{\circ} \mathrm{C}$. To highlight deoxyribose degradation, samples were heated for $20 \mathrm{~min}$ to generate malondialdehyde and incubated with thiobarbituric acid (14 $\mathrm{mM})$ in an acidic medium (trichloroacetic acid, $147 \mathrm{mM}$ ) to yield a pink chromogen. The absorbance was then measured by spectrophotometry at $532 \mathrm{~nm}$. Concentrations of $\mathrm{HO}$. in the samples $\left(\mathrm{nmol} \mathrm{mL}^{-1}\right)$ were determined by using a standard curve. The same experiments were also performed on the salivary sample and the intestinal digestion of blank SGID (SGID only with enzymes), which induce a decrease in $\mathrm{HO}$ production. To avoid any interference, $\mathrm{IC}_{50}$ values for the 11 protein samples (salivary sample and intestinal digestion) were calculated taking into account the individual effects of the blank SGID samples. 


\section{Results and Discussion}

Whey protein $(\mathrm{WhP})$ is used as an animal-based protein reference in this study, since dairy proteins and peptides have already been particularly explored in those contexts [29-31].

\subsection{Good Reproducibility of SGID Process and Peptide Generation}

The shapes of replicate chromatograms for each protein intestinal digestion (Supplementary Figures S1 to S11) are comparable, indicating that the SGID process is reproducible. Moreover, the shapes of chromatograms are not different when comparing SGID performed on the control WhP (Supplementary Figure S11) during the first (WhP-1, WhP-2, and WhP-3) and during the second study phases (WhP-4), indicating that both are comparable. Finally, the chromatogram obtained for the intestinal digestion of blank SGID (Supplementary Figure S12) and its comparison with all other chromatograms (Supplementary Figures S1 to S11) seem to indicate that the peptide profiles of intestinal digestions for each protein sample are only very slightly contaminated by non-specific peptides generated by the hydrolysis and autolysis of the digestive enzymes themselves (pepsin and pancreatin) in this SGID protocol.

Moreover, when comparing peptide size repartition in each protein intestinal digestion (Figure 1), SGID of WP1, WP2, and WhP generates longer peptides (>10,000 Da for WP2 and WhP and between 1000 and 10,000 Da for WP1). In contrast, SGID of HPeaP, FBP, and OP generates smaller peptides (between 250 and $1000 \mathrm{Da}$ for HPeaP and $<250$ Da for FBP and OP). Prior hydrolysis of pea protein (HPeaP) thus leads to smaller peptides than the four grades of pea proteins (PeaP1, PeaP2, PeaP3, and PeaP4), whose peptide size repartition is comparable.

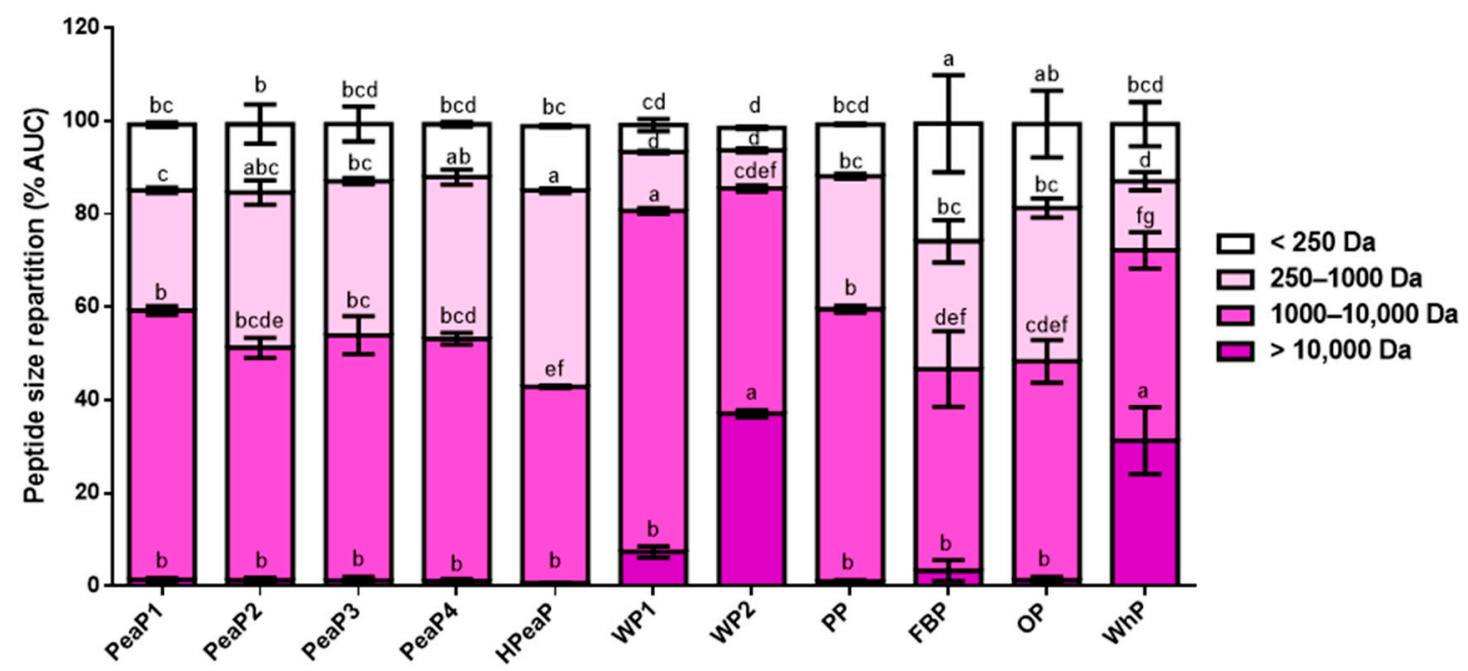

Figure 1. Peptide size repartition after SGID of the different protein samples (intestinal digestion). Values are reported as the mean from triplicate determinations with SD and are expressed in \% chromatogram AUC. Means for each peptide size class not sharing any common letter (a-g) are significantly different according to two-way ANOVA procedure followed by Tukey's test. PeaP1-PeaP4 (4 grades of pea protein), HPeaP (hydrolyzed pea protein), WP1-WP2 (2 grades of wheat protein), PP (potato protein), FBP (fava bean protein), OP (oat protein) and WhP (Whey protein).

These results indicate that the SGID of the different protein samples generates peptides with different sizes, sequences, and structures. This could explain the differences observed in terms of bioactivities.

\subsection{Dose-Dependent Increase in CCK and GLP-1 Secretion in Response to Intestinal Digestions (after SGID)}

Digested bovine hemoglobin is used as a positive control since its important effect on intestinal hormone secretion has already been demonstrated [22]. 
For all the samples and conditions tested, the intestinal digestion (after SGID) leads to a better induction of CCK (Figure 2) and GLP-1 (Figure 3) secretion by STC-1 cells than the salivary sample (before SGID), even if some studies indicate that intact proteins can be more potent than hydrolysates [32,33]. Moreover, the incubation of STC-1 cells with the different intestinal digestions increases CCK and GLP-1 secretion in a dose-dependent manner.
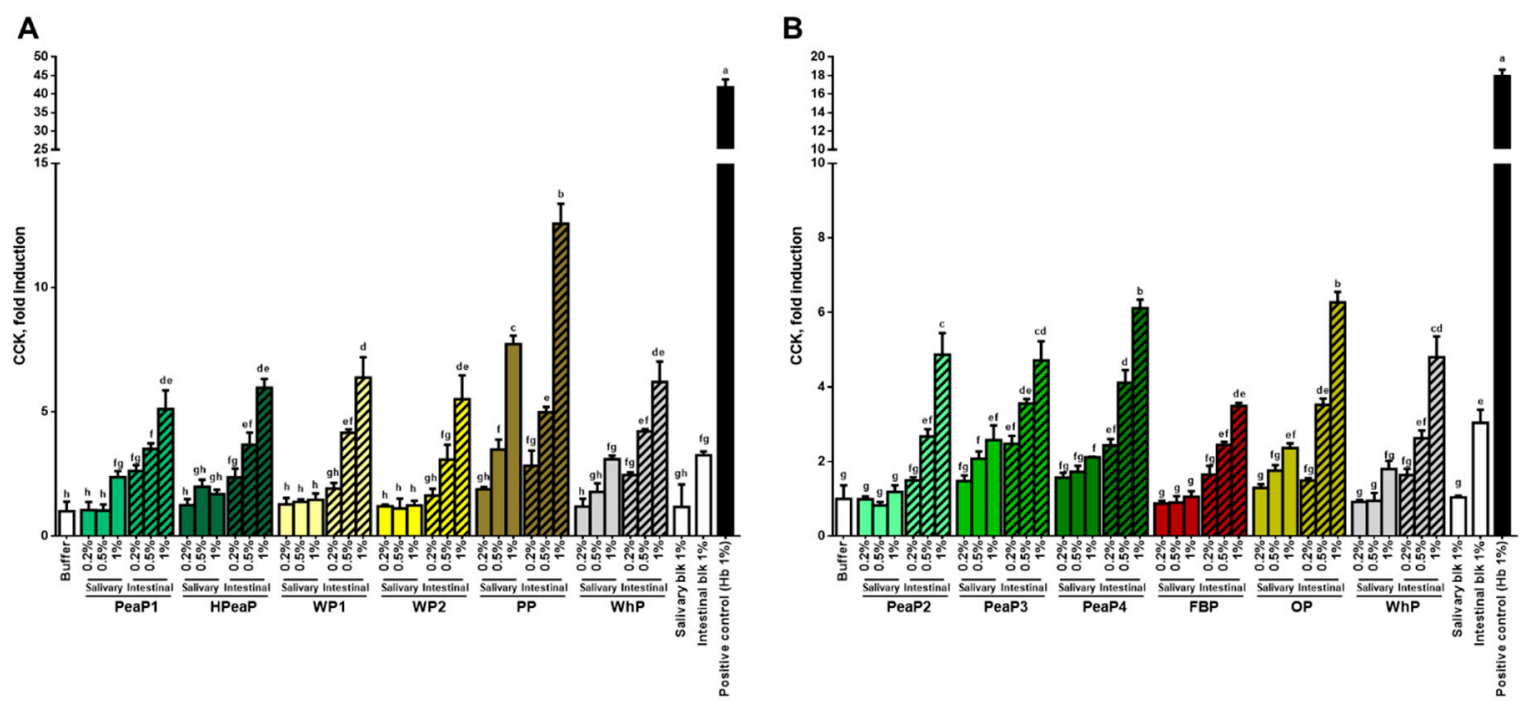

Figure 2. STC-1 cells were incubated for $2 \mathrm{~h}$ with different final concentrations $(0.2,0.5$, and $1 \%$ dry matter) of the protein samples of the first (A) and the second phase (B), before (salivary sample) and after SGID (intestinal digestion). CCK levels were determined by RIA and expressed as \% of control (buffer) levels. Data are expressed in mean $(n=3) \pm$ SD. Means without a common letter $(\mathrm{a}-\mathrm{h})$ are different $(p<0.05)$ according to one-way ANOVA procedure followed by Tukey's test. PeaP1-PeaP4 (4 grades of pea protein), HPeaP (hydrolyzed pea protein), WP1-WP2 (2 grades of wheat protein), $\mathrm{PP}$ (potato protein), FBP (fava bean protein), OP (oat protein) and WhP (Whey protein).
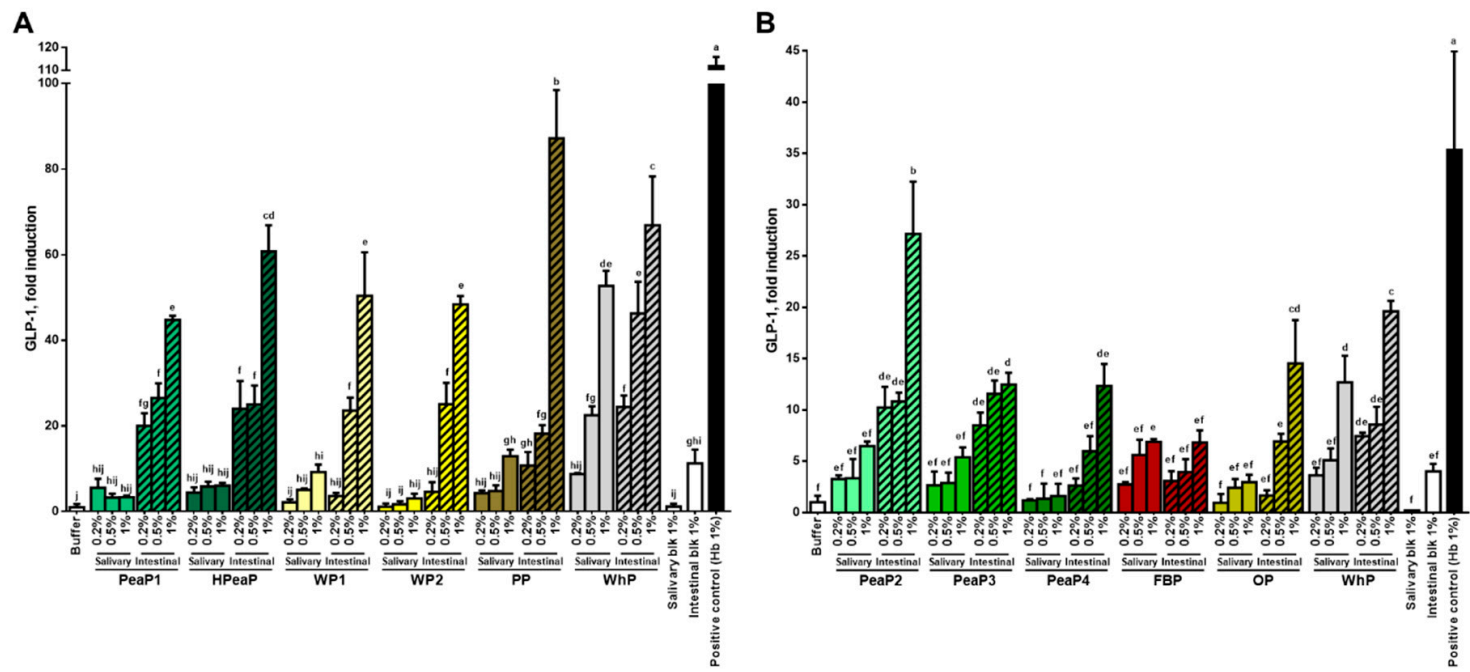

Figure 3. STC-1 cells were incubated for $2 \mathrm{~h}$ with different final concentrations $(0.2,0.5$, and $1 \%$ dry matter) of the protein samples of the first (A) and the second phase (B), before (salivary sample) and after SGID (intestinal digestion). GLP-1 levels were determined by RIA and expressed as \% of control (buffer) levels. Data are expressed in mean $(n=3) \pm \mathrm{SD}$. Means without a common letter (a-j) are different $(p<0.05)$ according to one-way ANOVA procedure followed by Tukey's test. PeaP1-PeaP4 (4 grades of pea protein), HPeaP (hydrolyzed pea protein), WP1-WP2 (2 grades of wheat protein), PP (potato protein), FBP (fava bean protein), OP (oat protein) and WhP (Whey protein). 
Furthermore, as a reference, the levels of CCK secretion induced by WhP after SGID during the first phase (Figure 2A) and during the second study phase (Figure 2B) are comparable; indeed, the incubation of STC-1 cells with the intestinal digestion of WhP (final concentration 1\%) leads to a CCK secretion of $63.80 \pm 8.38 \mathrm{pM}$ (or $\sim 6$-fold increase compared to the buffer control) during the first phase (Figure 2A) and of $60.17 \pm 7.07 \mathrm{pM}$ (or $\sim 5$-fold increase compared to the buffer control) during the second phase (Figure 2B). This indicates that the two phases of the CCK secretion study are comparable.

However, when comparing the impact of SGID performed on WhP during the first phase (Figure 3A) and during the second study phase (Figure 3B) on GLP-1 secretion, there are some differences. Indeed, the incubation of STC-1 cells with the intestinal digestion of WhP (final concentration 1\%) leads to a $\sim 60$-fold increase in GLP-1 secretion compared to the buffer control during the first phase (Figure 3A), whereas it reaches a $\sim 20$-fold increase in GLP-1 secretion compared to the buffer control during the second phase (Figure 3B). In any case, this 3-fold difference between the first and the second phases can also be detected for other samples which are common to the two phases of the study (Figure 3) like the intestinal digestion obtained after blank SGID (intestinal blk 1\%) and the positive control (bovine hemoglobin $\mathrm{Hb}$ 1\%), leading to the conclusion that STC-1 cells were not as responsive regarding GLP-1 secretion in the second study phase as in the first one. Nevertheless, the two phases of the study can be compared based on GLP-1 secretion induced by WhP.

The incubation of STC-1 cells with the intestinal digestion obtained after blank SGID (intestinal blk 1\%) leads to a 3-fold increase in CCK secretion (Figure 2) and also an increase in GLP-1 secretion compared to the buffer control (Figure 3). However, all intestinal digestions tested at this concentration (1\%) lead to a higher CCK (between 5- and 12-fold) and GLP-1 secretion than the intestinal blank. The compound inducing the best CCK secretion is PP (Figure 2A) and the ones inducing the best GLP-1 secretion are PP (Figure 3A) and PeaP2 (Figure 3B).

Numerous studies using different in vitro and in vivo models have already demonstrated the effect of hydrolysates obtained from various protein sources like milk [31], meat [22], fish and crustaceans [34,35], and plants [36] on gut hormone secretion. Nevertheless, only few studies aim at comparing the effects of several protein sources. One of them has compared the effect of pea, potato, soy, whey, and casein protein hydrolysates on CCK secretion using STC-1 cells but no significant differences in impact were observed between the different hydrolysates [37]. Another study has shown that pea and wheat proteins were the most potent stimulators of CCK and GLP-1 release from human duodenal biopsies in Ussing Chambers compared to animal proteins like ovomucoid, egg, and codfish proteins [38]. Recently, it has been highlighted that wheat gluten hydrolysate more potently stimulated GLP-1 secretion by GLUTag cells than lactalbumin enzymatic hydrolysate [39].

The present study allows the direct comparison, in the same conditions, between different plant-based proteins and whey protein and reveal that all proteins tested, once digested, stimulate CCK and GLP-1 secretion by STC-1 cells, potato and pea proteins being the most potent stimulators.

\subsection{Good Inhibition of DPP-IV Activity by Intestinal Digestions (after SGID)}

For all proteins, the intestinal digestion (after SGID) leads to better inhibition of DPP-IV activity (Table 4) than the gastric digestion (during SGID) and salivary sample (before SGID). The results indicate that the SGID of these 11 protein samples generates potential bioactive peptides, which are effective DPP-IV activity inhibitors since $\mathrm{IC}_{50}$ values for intestinal digestions are between $\sim 0.5$ and $2 \mathrm{mg} \mathrm{mL}^{-1}$ (Table 4), the best ones being HPeaP, FBP, and OP with, respectively, $\mathrm{IC}_{50}$ values of $0.79 \pm 0.08,0.54 \pm 0.03$, and $0.83 \pm 0.10 \mathrm{mg} \mathrm{mL}^{-1}$ (intestinal digestion). Interestingly, the SGID of these three protein samples is shown to generate smaller peptides (Figure 1). Moreover, whereas SGID of the WP2 is shown to generate longer peptides (Figure 1), its $\mathrm{IC}_{50}$ value for DPP-IV activity is the highest in this study $\left(2.03 \pm 0.30 \mathrm{mg} \mathrm{mL}^{-1}\right.$ (intestinal digestion)), suggesting peptide size is important for this activity. Then, the same experiment was performed on the blank SGID (only with enzymes) and no DPP-IV inhibitory activity was detected in this intestinal digestion. 
Table 4. Inhibitory concentration inducing 50\% DPP-IV activity inhibition ( $\left.\mathrm{IC}_{50}\right)$ of the 11 protein samples before (salivary sample), during (gastric digestion), and after SGID (intestinal digestion).

\begin{tabular}{|c|c|c|c|}
\hline DPP-IV-IC ${ }_{50}\left(\mathrm{mg} \mathrm{mL}^{-1}\right)$ & Salivary Sample & Gastric Digestion & Intestinal Digestion \\
\hline PeaP1 & ND & $1.13 \pm 0.05^{C D}$ & $1.07 \pm 0.06^{\text {bcde }}$ \\
\hline PeaP2 & $3.87 \pm 1.01$ & $0.85 \pm 0.19 \mathrm{CD}$ & $0.98 \pm 0.55^{\text {cde }}$ \\
\hline PeaP3 & ND & $1.45 \pm 0.15^{\mathrm{BCD}}$ & $1.19 \pm 0.05^{\mathrm{bcd}}$ \\
\hline PeaP4 & ND & $2.34 \pm 1.18 \mathrm{AB}$ & $1.46 \pm 0.17^{b c}$ \\
\hline HPeaP & $1.19 \pm 0.12$ & $0.86 \pm 0.08 \mathrm{CD}$ & $0.79 \pm 0.08$ de \\
\hline WP1 & ND & $2.96 \pm 0.34^{\mathrm{A}}$ & $1.64 \pm 0.07^{\mathrm{ab}}$ \\
\hline WP2 & ND & $2.96 \pm 0.51^{\mathrm{A}}$ & $2.03 \pm 0.30^{\mathrm{a}}$ \\
\hline PP & ND & $1.88 \pm 0.21 \mathrm{ABC}$ & $1.07 \pm 0.12$ bcde \\
\hline FBP & ND & $0.65 \pm 0.07^{\mathrm{D}}$ & $0.54 \pm 0.03 \mathrm{e}^{\mathrm{C}}$ \\
\hline OP & ND & $0.75 \pm 0.07 \mathrm{CD}$ & $0.83 \pm 0.10^{\text {cde }}$ \\
\hline WhP & ND & $1.70 \pm 0.10^{\mathrm{BCD}}$ & $1.02 \pm 0.14$ bcde \\
\hline
\end{tabular}

Values are reported as the mean from triplicate determinations with $\mathrm{SD}$. "ND" indicates the $\mathrm{IC}_{50}$ value was too high to be evaluated using this test. Values not sharing any common superscript letter are significantly different according to one-way ANOVA procedure followed by Tukey's test (intestinal digestions were compared together (a-e, small letters) and gastric digestions together (A-D, capital letters)). PeaP1-PeaP4 (4 grades of pea protein), HPeaP (hydrolyzed pea protein), WP1-WP2 (2 grades of wheat protein), PP (potato protein), FBP (fava bean protein), $\mathrm{OP}$ (oat protein) and WhP (Whey protein).

$\mathrm{IC}_{50}$ values for DPP-IV activity obtained in this study are really remarkable, since $\mathrm{IC}_{50}$ values of various digestions are known to generally range from 1 to $5 \mathrm{mg} \mathrm{mL}^{-1}$. As an example, in the literature, $\mathrm{IC}_{50}$ values for digested bovine hemoglobin and cuttlefish are, respectively, 1.62 and $2.15 \mathrm{mg} \mathrm{mL}^{-1}$ [40]; for digested milk protein isolate, it is $0.65 \pm 0.06 \mathrm{mg} \mathrm{mL}^{-1}$ [41]; for digested hemp, pea, rice, and soy protein isolate, it is between $1.85 \pm 0.34$ and $4.50 \pm 0.55 \mathrm{mg} \mathrm{mL}^{-1}$ [42]. A recent review has listed dietary protein-derived hydrolysates displaying $\mathrm{IC}_{50}$ lower than $1 \mathrm{mg} \mathrm{mL}^{-1}$ [17], in which digested oat flour is reported $\left(0.99 \mathrm{mg} \mathrm{mL}^{-1}[43]\right)$.

The present study allows highlighting of the potency of different digested plant-based proteins as DPP-IV inhibitors, pea, fava bean, and oat proteins being the most effective. These results could be confirmed using more biological relevant models and cell lines expressing DPP-IV-like Caco-2 cells [40]. Nevertheless, the impact of the brush barrier peptidases activity on the DPP-IV inhibitory peptides and their passage through the brush border membrane has yet to be investigated to evaluate their potential to inhibit plasma DPP-IV activity.

\subsection{Good Potential to Bind Opioid Receptors by Protein Samples}

All samples tested (salivary sample (before SGID) and intestinal digestion (after SGID)) can potentially bind opioid receptors (Table 5). Moreover, SGID does not always lead to an improvement of the potential binding of the sample on opioid receptors, since $\mathrm{ED}_{50}$ values for salivary sample and intestinal digestion are comparable, like for PeaP2, PeaP3, HPeaP, and PP. Nevertheless, the SGID process improves opioid receptor binding for PeaP1, PeaP4, WP1, WP2, OP, and WhP. In one case, SGID process decreases opioid receptor binding (FBP).

The samples having the highest affinity for opioid receptors are PeaP2 and PeaP3 with, respectively, an $\mathrm{ED}_{50}$ value of 4.98 and $4.63 \mathrm{mg} \cdot \mathrm{mL}^{-1}$ before SGID (salivary sample) and 4.23 and $2.44 \mathrm{mg} \cdot \mathrm{mL}^{-1}$ after SGID (intestinal digestion) (Table 5). The same experiment was performed on the blank SGID (only with enzymes) and no binding on opioid receptors was detected in this sample.

A lot of peptides, derived from food proteins like casein and lactalbumin (milk), glutenin and gliadin (wheat), RuBisCo (spinach), or $\beta$-conglycinin (soybean), are known to be recognized by opioid receptors, and display opioid-like molecular and physiological activities [44].

The present study allows us to highlight new proteins, digested or intact, able to bind opioid receptors, pea proteins being the most effective. Nevertheless, the passage of protein/peptide sequences, through the brush border membrane, has yet to be investigated as it has been shown for hemorphin peptides generated by SGID of bovine hemoglobin [45], to further evaluate their potential to bind peripheral opioid receptors in the portal vein, leading to the regulation of food intake. Moreover, 
food-derived opioid peptides could also reach the brain and thus, be implicated in several other biological functions, as they were able to cross the blood-brain barrier in vitro [45].

Table 5. $\mathrm{ED}_{50}$ values expressed in $\mathrm{mg} \mathrm{mL}^{-1}$ (dry matter) for opioid receptor binding for each of the 11 protein samples before (salivary sample) and after SGID (intestinal digestion).

\begin{tabular}{|c|c|c|}
\hline Opioid R-ED $50\left(\mathrm{mg} \mathrm{mL}^{-1}\right)$ & Salivary Sample & Intestinal Digestion \\
\hline PeaP1 & 26.80 & 14.90 \\
\hline PeaP2 & 4.98 & 4.23 \\
\hline PeaP3 & 4.63 & 2.44 \\
\hline PeaP4 & 24.98 & 3.17 \\
\hline HPeaP & 8.60 & 10.27 \\
\hline WP1 & 39.50 & 26.73 \\
\hline WP2 & 80.30 & 17.90 \\
\hline PP & 14.55 & 15.40 \\
\hline FBP & 2.83 & 12.51 \\
\hline OP & 31.03 & 10.25 \\
\hline WhP & 78.21 & 22.70 \\
\hline
\end{tabular}

PeaP1-PeaP4 (4 grades of pea protein), HPeaP (hydrolyzed pea protein), WP1-WP2 (2 grades of wheat protein), PP (potato protein), FBP (fava bean protein), OP (oat protein) and WhP (Whey protein).

\subsection{Good Inhibition of ACE Activity by Intestinal Digestions (after SGID)}

The SGID of the 11 protein samples generates potential bioactive peptides which are good ACE activity inhibitors, since $\mathrm{IC}_{50}$ values for intestinal digestions are between $\sim 30$ and $300 \mu \mathrm{g} \mathrm{mL}-1$ (Table 6), the best ones being PeaP4 with an $\mathrm{IC}_{50}$ value of $29.54 \pm 34.98 \mu \mathrm{g} \mathrm{mL}^{-1}$ (intestinal digestion), WP1 with an $\mathrm{IC}_{50}$ value of $63.82 \pm 20.18 \mu \mathrm{g} \mathrm{mL} \mathrm{L}^{-1}$ (intestinal digestion), PP with an $\mathrm{IC}_{50}$ value of $85.23 \pm 19.24 \mu \mathrm{g} \mathrm{mL}^{-1}$ (intestinal digestion), and FBP with an $\mathrm{IC}_{50}$ value of $52.02 \pm 43.06 \mu \mathrm{gL}^{-1}$ (intestinal digestion). Moreover, the same experiment was performed on the blank SGID (only with enzymes) and no ACE inhibitory activity was detected in this sample.

Table 6. Inhibitory concentration inducing $50 \%$ ACE activity inhibition $\left(\mathrm{IC}_{50}\right)$ of the 11 protein samples before (salivary sample), during (gastric digestion), and after SGID (intestinal digestion).

\begin{tabular}{cccc}
\hline ACE-IC $_{\mathbf{5 0}}\left(\boldsymbol{\mu} \mathbf{g ~ \mathbf { ~ m L } ^ { - 1 } )}\right.$ & Salivary Sample & Gastric Digestion & Intestinal Digestion \\
\hline PeaP1 & ND & $90.70 \pm 25.80^{\mathrm{CD}}$ & $101.19 \pm 23.15^{\mathrm{cd}}$ \\
PeaP2 & $407.78 \pm 28.10$ & $37.37 \pm 19.83^{\mathrm{D}}$ & $221.79 \pm 45.57^{\mathrm{ab}}$ \\
PeaP3 & ND & $47.38 \pm 44.33^{\mathrm{CD}}$ & $185.54 \pm 9.97^{\mathrm{abc}}$ \\
PeaP4 & ND & $187.97 \pm 45.38^{\mathrm{AB}}$ & $29.54 \pm 34.98^{\mathrm{d}}$ \\
HPeaP & $148.97 \pm 40.79$ & $93.37 \pm 24.74 \mathrm{CD}$ & $113.64 \pm 50.51^{\mathrm{cd}}$ \\
WP1 & ND & $60.79 \pm 12.22^{\mathrm{CD}}$ & $63.82 \pm 20.18^{\mathrm{d}}$ \\
WP2 & ND & $186.78 \pm 0.91^{\mathrm{AB}}$ & $265.46 \pm 22.88^{\mathrm{a}}$ \\
PP & ND & $107.34 \pm 40.79^{\mathrm{BCD}}$ & $85.23 \pm 19.24^{\mathrm{d}}$ \\
FBP & ND & $133.50 \pm 35.09^{\mathrm{BC}}$ & $52.02 \pm 43.06^{\mathrm{d}}$ \\
OP & ND & $98.04 \pm 32.21^{\mathrm{CD}}$ & $99.46 \pm 9.88^{\mathrm{cd}}$ \\
WhP & ND & $126.38 \pm 82.34^{\mathrm{BCD}}$ & $127.50 \pm 25.61^{\mathrm{bcd}}$ \\
\hline
\end{tabular}

Values are reported as the mean from triplicate determinations with SD. "ND" indicates the $\mathrm{IC}_{50}$ value was too high to be evaluated using this test. Values not sharing any common superscript letter are significantly different according to one-way ANOVA procedure followed by Tukey's test (intestinal digestions were compared together (a-d, small letters) and gastric digestions together (A-D, capital letters)). PeaP1-PeaP4 (4 grades of pea protein), HPeaP (hydrolyzed pea protein), WP1-WP2 (2 grades of wheat protein), PP (potato protein), FBP (fava bean protein), $\mathrm{OP}$ (oat protein) and WhP (Whey protein).

Peptides with ACE-inhibiting activity have been detected in various sources including milk, eggs, meat, plants, and fish [46,47]. IC 50 values for ACE activity obtained in this study are satisfying since they are comparable with other studies performed on peptides from different sources [48]. A study has compared the ACE-inhibitory activity of the hydrolysates obtained by the pepsin digestion of some plant-based proteins, such as chickpea, common bean, lentil, lupin, pea, and soybean, the most efficient being soybean and lupin with respective $\mathrm{IC}_{50}$ values of 224 and $226 \mu \mathrm{g} \mathrm{mL}^{-1}$ [49]. Another study has identified ACE-inhibiting peptides in enzymatic hydrolysates of plant-based proteins such as rice, soy, pea, and wheat, with $\mathrm{IC}_{50}$ values ranging from 27 to $39 \mu \mathrm{g} \mathrm{mL}^{-1}$ [50]. 
The present study allows highlighting of the potency of different digested plant-based proteins as ACE inhibitors, pea, wheat, potato, and fava bean being the most effective. These results should be confirmed using, for instance, cell models expressing ACE.

\subsection{No Effect on Pro-Inflammatory Cytokine Secretion by Protein Samples}

Incubation with the salivary sample (before SGID) of PeaP1, PeaP3, PeaP4, and OP significantly increases IL-8 secretion, with or without pre-inflammation with LPS, suggesting a pro-inflammatory effect of these protein samples (Figure 4). However, this increase is not observed following incubation of these four protein samples after SGID, suggesting that they are no more pro-inflammatory after digestion. This can be explained by the destruction of certain inflammatory peptide structures by digestive enzymes during SGID. A similar but slighter effect of the SGID can also be observed for WP1 and WhP without pre-inflammation with LPS (Figure 4).

A
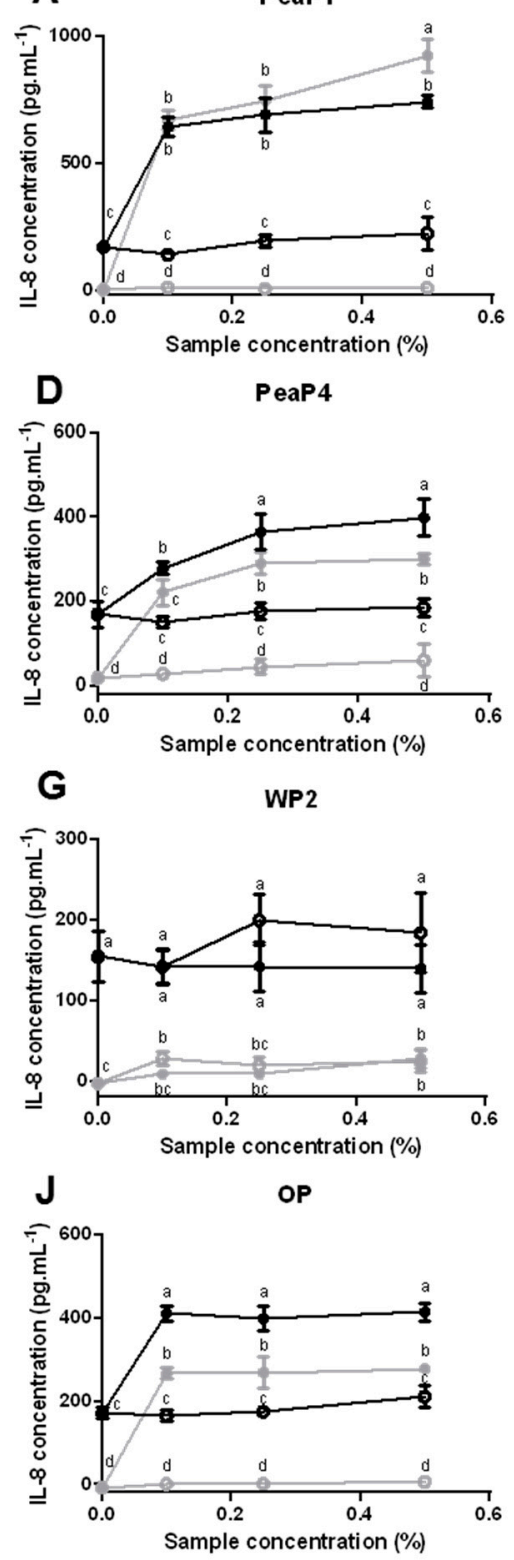
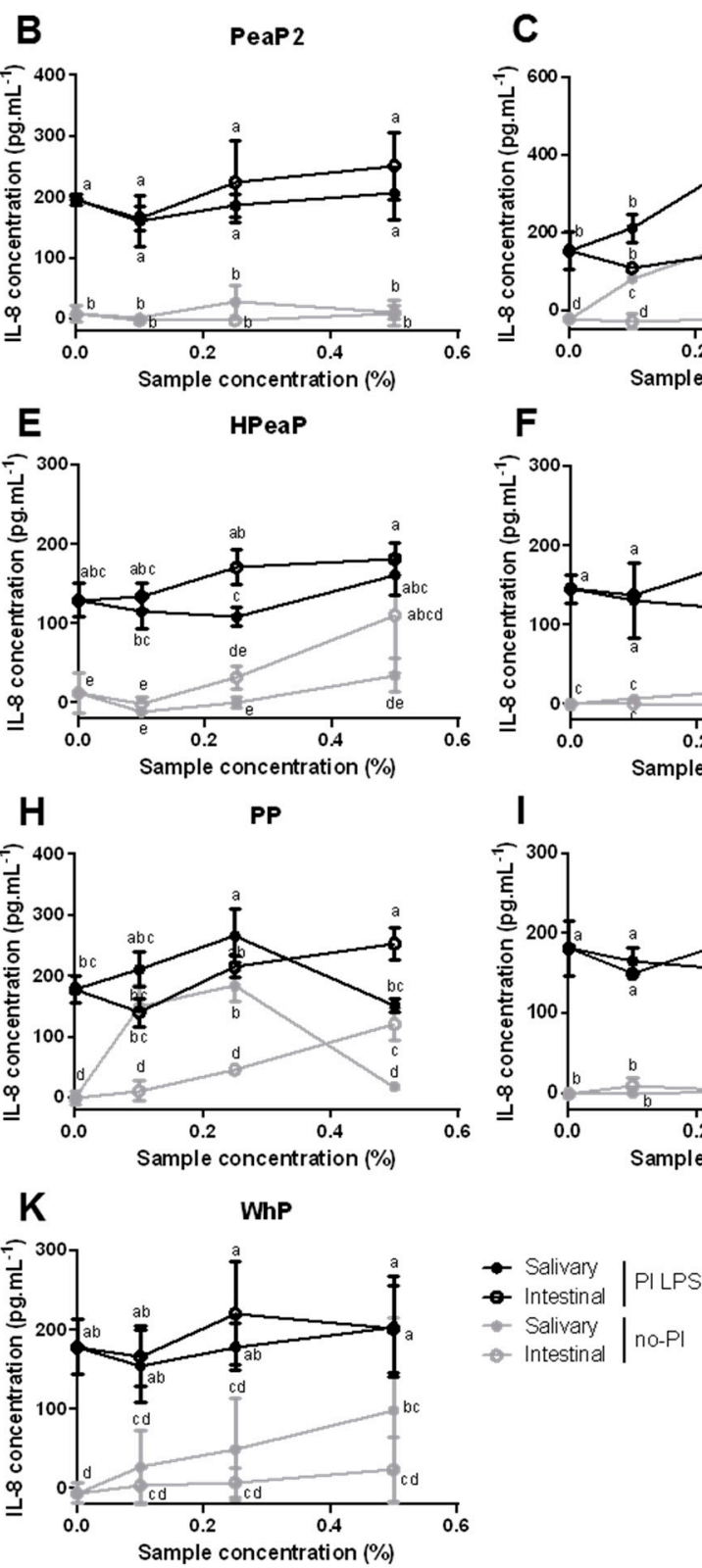
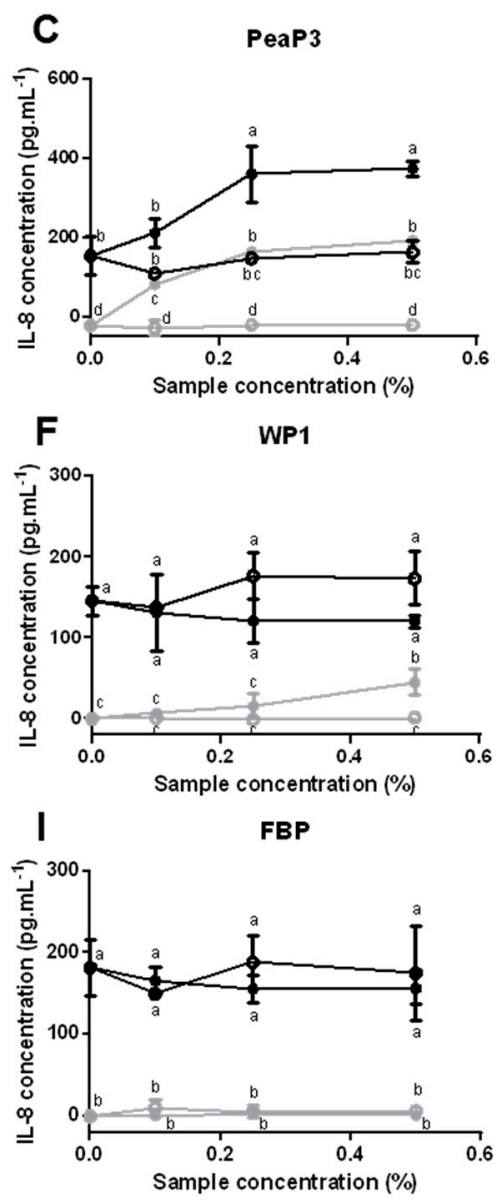

Figure 4. Differentiated Caco-2 cells were pre-incubated (PI-black) or not (no-PI-grey) with $20 \mu \mathrm{g} . \mathrm{mL}^{-1}$ LPS for $24 \mathrm{~h}$ and then, incubated with different final concentrations $(0.1,0.25$, and $0.5 \%$ dry matter) of 
the 11 protein samples, before (salivary sample—filled circles) and after SGID (intestinal digestionempty circles) for $24 \mathrm{~h}$. IL-8 levels were determined by ELISA and expressed in $\mathrm{pg} \mathrm{mL}^{-1}$. Data are expressed in mean $(n=3) \pm \mathrm{SD}$. Means without a common letter (a-e) are different $(p<0.05)$ according to two-way ANOVA procedure followed by Tukey's test. (A-D): PeaP1-PeaP4 (4 grades of pea protein), (E): HPeaP (hydrolyzed pea protein), (F,G): WP1-WP2 (2 grades of wheat protein), (H): PP (potato protein), (I): FBP (fava bean protein), (J): OP (oat protein) and (K): WhP (Whey protein).

Moreover, the results indicate that incubation with intestinal digestions of the 11 protein samples does not lead to significant changes in IL-8 secretion by Caco-2 cells pre-inflamed or not with LPS and thus, does not highlight any pro- or anti-inflammatory properties of the samples on cytokine secretion (Figure 4).

Peptides with anti-inflammatory activity have been detected in various sources including milk casein, wheat gluten, egg ovotransferrin, and soybean protein [51]. The present study does not allow us to highlight the anti-inflammatory properties of the different proteins tested, digested or intact, on LPS-induced IL-8 secretion by Caco-2 cells. However, some further analyses including the use of TNF- $\alpha$ [52] or IL-1 $\beta$ [53] as inflammation inducers, other cytokines, or prostaglandins and cell models are needed to evaluate their potential role in inflammation processes to complete the present study. Moreover, it would be interesting to use a model of co-culture Caco-2/immune cells.

\subsection{Antioxidant Properties of Protein Samples (after SGID)}

\subsubsection{Superoxide Anion Assay}

Only salivary samples of PeaP1, WP2, PP, and OP decrease $\mathrm{O}_{2}^{-}$production (Table 7) but this antioxidant activity is lost after SGID (intestinal digestion), except for PP which is still able to decrease $\mathrm{O}_{2}{ }^{-}$production.

Table 7. Inhibitory concentration inducing $50 \% \mathrm{O}_{2}{ }^{-}$production inhibition $\left(\mathrm{IC}_{50}\right)$ of the 11 protein samples before (salivary sample) and after SGID (intestinal digestion).

\begin{tabular}{ccc}
\hline $\mathbf{O}_{\mathbf{2}}{ }^{-}-\mathbf{I C}_{\mathbf{5 0}}\left(\mathbf{m g} \mathbf{~ m L}^{-\mathbf{1}}\right)$ & Salivary Sample & Intestinal Digestion \\
\hline PeaP1 & 0.70 & ND \\
PeaP2 & ND & ND \\
PeaP3 & ND & ND \\
PeaP4 & ND & ND \\
HPeaP & ND & ND \\
WP1 & ND & ND \\
WP2 & 1.30 & ND \\
PP & 2.00 & 1.80 \\
FBP & ND & ND \\
OP & 2.50 & ND \\
WhP & ND & ND
\end{tabular}

Values are reported as the mean from triplicate determinations. $\mathrm{IC}_{50}$ values are expressed in $\mathrm{mg} \mathrm{mL}^{-1}$ (dry matter). $\mathrm{IC}_{50}$ values, which could not be determined (higher than $5 \mathrm{mg} \mathrm{mL}^{-1}$ ), are represented by "ND". PeaP1-PeaP4 (4 grades of pea protein), HPeaP (hydrolyzed pea protein), WP1-WP2 (2 grades of wheat protein), PP (potato protein), FBP (fava bean protein), OP (oat protein) and WhP (Whey protein).

\subsubsection{Hydrogen Peroxide Assay}

Most of the samples (salivary samples and intestinal digestions) decrease $\mathrm{H}_{2} \mathrm{O}_{2}$ production (Table 8). PeaP1, PeaP2, HPeaP, PP, and FBP exhibit a good $\mathrm{IC}_{50}$ value before and after SGID, while PeaP3 and OP inhibit more $\mathrm{H}_{2} \mathrm{O}_{2}$ production before than after SGID. Finally, WhP inhibits more $\mathrm{H}_{2} \mathrm{O}_{2}$ production after than before SGID. 
Table 8. Inhibitory concentration inducing $50 \% \mathrm{H}_{2} \mathrm{O}_{2}$ production inhibition $\left(\mathrm{IC}_{50}\right)$ of the 11 protein samples before (salivary sample) and after SGID (intestinal digestion).

\begin{tabular}{ccc}
\hline $\mathbf{H}_{\mathbf{2}} \mathbf{O}_{\mathbf{2}}-\mathbf{I C}_{\mathbf{5 0}}\left(\mathbf{m g ~ m L}^{-\mathbf{1}}\right)$ & Salivary Sample & Intestinal Digestion \\
\hline PeaP1 & 0.65 & 0.55 \\
PeaP2 & 0.65 & 1.40 \\
PeaP3 & 0.80 & 4.60 \\
PeaP4 & 1.05 & ND \\
HPeaP & 0.65 & 1.20 \\
WP1 & ND & ND \\
WP2 & 2.10 & ND \\
PP & 0.65 & 1.20 \\
FBP & 0.65 & 0.65 \\
OP & 0.75 & 3.05 \\
WhP & 4.45 & 2.08
\end{tabular}

Values are reported as the mean from triplicate determinations. $\mathrm{IC}_{50}$ values are expressed in $\mathrm{mg} \mathrm{mL}^{-1}$ (dry matter). $\mathrm{IC}_{50}$ values which could not be determined (higher than $5 \mathrm{mg} \cdot \mathrm{mL}^{-1}$ ) are represented by "ND". PeaP1-PeaP4 (4 grades of pea protein), HPeaP (hydrolyzed pea protein), WP1-WP2 (2 grades of wheat protein), PP (potato protein), FBP (fava bean protein), OP (oat protein) and WhP (Whey protein).

\subsubsection{Hydroxyl Radical Assay}

All samples (salivary samples and intestinal digestions) decrease HO production (Table 9). Most of the samples, such as PeaP1, PeaP2, PeaP3, PeaP4, HPeaP, WP2, PP, FBP, and OP, exhibit a good $\mathrm{IC}_{50}$ value before and after SGID, while WP1 and WhP inhibit more HO production after than before SGID.

Table 9. Inhibitory concentration inducing $50 \% \mathrm{HO}$ production inhibition $\left(\mathrm{IC}_{50}\right)$ of the 11 protein samples before (salivary sample) and after SGID (intestinal digestion).

\begin{tabular}{ccc}
\hline HO-IC $_{\mathbf{5 0}}\left(\mathbf{m g ~ m L}^{-\mathbf{1}}\right)$ & Salivary Sample & Intestinal Digestion \\
\hline PeaP1 & 1.60 & 2.05 \\
PeaP2 & 1.25 & 1.00 \\
PeaP3 & 1.10 & 1.55 \\
PeaP4 & 1.60 & 1.35 \\
HPeaP & 1.45 & 2.50 \\
WP1 & 4.50 & 1.65 \\
WP2 & 1.35 & 0.85 \\
PP & 1.00 & 1.75 \\
FBP & 1.30 & 1.45 \\
OP & 1.50 & 1.70 \\
WhP & 2.95 & 1.33 \\
\hline
\end{tabular}

Values are reported as the mean from triplicate determinations. $\mathrm{IC}_{50}$ values are expressed in $\mathrm{mg} \mathrm{mL}^{-1}$ (dry matter). PeaP1-PeaP4 (4 grades of pea protein), HPeaP (hydrolyzed pea protein), WP1-WP2 (2 grades of wheat protein), PP (potato protein), FBP (fava bean protein), OP (oat protein) and WhP (Whey protein).

PP is the only sample that inhibits $\mathrm{O}_{2}{ }^{-}, \mathrm{H}_{2} \mathrm{O}_{2}$, and $\mathrm{HO}$ production before (salivary sample) and after (intestinal digestion) SGID. All samples are able to inhibit HO production after SGID (intestinal digestions) and most of them are able to inhibit $\mathrm{H}_{2} \mathrm{O}_{2}$ production too after SGID (PeaP1, PeaP2, PeaP3, HPeaP, PP, FBP, OP, and WhP).

The composition of the samples, for instance, the release during digestion of small peptides with a thiol function could explain a powerful antioxidant effect. Food protein hydrolysates and peptides with antioxidant activity have been detected in various sources [54]. However, the antioxidant properties are determined mostly based on in vitro ability to scavenge free radicals, reduce ferric iron to ferrous, bind metals, and inhibit lipid oxidation.

The present study allows highlighting of, for the first time, the antioxidant properties of the different plant-based proteins, digested or intact, directly on ROS production using original tests, potato protein being the most effective. 


\section{Conclusions}

In this study, 10 plant-based protein samples_four grades of pea protein (PeaP1, PeaP2, PeaP3, and PeaP4) and a hydrolyzed pea protein (HPeaP), two grades of wheat protein (WP1 and WP2), and potato, fava bean, and oat proteins (PP, FBP, and OP)—-were submitted to SGID. Whey protein $(\mathrm{WhP})$ was used as an animal-sourced protein reference. Undigested and digested protein samples were then tested in vitro to investigate their ability to modulate food intake and glucose homeostasis through CCK and GLP-1 secretion, DPP-IV activity, and opioid receptor binding. They were also evaluated for their ACE-inhibitory activity but also their anti-inflammatory and antioxidant properties. The best candidates answering globally to the main activities explored were PeaP1, PeaP2, HPeaP, PP, and FBP with some specificities (Table 10). Natural peptides could offer safer alternatives to some drugs, either in a curative or in a preventive context like functional foods and personalized nutrition. Nevertheless, further exploration and in vivo validation are needed to investigate whether these protein samples could be potentially valorized in the future in the context of obesity, T2DM, and related cardiovascular risk prevention, or for their antioxidant properties in the context of cardiovascular diseases or aging.

Table 10. Bioactivity scores of the 11 protein samples.

\begin{tabular}{ccccccccccc}
\hline \multirow{2}{*}{ Protein } & \multicolumn{3}{c}{ Metabolic Activity } & & $\begin{array}{c}\text { Anti- } \\
\text { Hypertensive }\end{array}$ & $\begin{array}{c}\text { Anti- } \\
\text { Inflammatory }\end{array}$ & \multicolumn{2}{c}{ Antioxidant } & SCORE \\
\cline { 2 - 8 } & CCK & GLP-1 & DPP-IV & OR & ACE & IL-8 & $\mathbf{O}_{\mathbf{2}}{ }^{-}$ & $\mathbf{H}_{\mathbf{2}} \mathbf{O}_{\mathbf{2}}$ & HO- & \\
\hline PeaP1 & 1 & 1 & 2 & 1 & 2 & 0 & 0 & 2 & 1 & 10 \\
PeaP2 & 1 & 2 & 2 & 2 & 1 & 0 & 0 & 2 & 1 & 11 \\
PeaP3 & 1 & 1 & 1 & 2 & 1 & 0 & 0 & 1 & 1 & 8 \\
PeaP4 & 1 & 1 & 1 & 2 & 2 & 0 & 0 & 0 & 1 & 8 \\
HPeaP & 1 & 1 & 2 & 1 & 2 & 0 & 0 & 2 & 1 & 10 \\
WP1 & 1 & 1 & 1 & 1 & 2 & 0 & 0 & 0 & 1 & 7 \\
WP2 & 1 & 1 & 1 & 1 & 1 & 0 & 0 & 0 & 1 & 6 \\
PP & 2 & 2 & 2 & 1 & 2 & 0 & 2 & 2 & 1 & 14 \\
FBP & 1 & 1 & 2 & 1 & 2 & 0 & 0 & 2 & 1 & 10 \\
OP & 1 & 1 & 2 & 1 & 2 & 0 & 0 & 1 & 1 & 9 \\
WhP & 1 & 1 & 2 & 1 & 2 & 0 & 0 & 1 & 1 & 9 \\
\hline
\end{tabular}

The present study also allows the screening and comparison of the effects of different digested plant-based proteins on numerous bioactivities, using the same tests and in the same conditions. These tests present some limitations, but this study allows us to characterize numerous proteins based on their bioactivities and their health potential and not only based on their amino acid composition and digestibility. Then, this study demonstrates that the SGID of different protein samples generates peptides with different sizes, sequences, and structures. These differences of peptide populations lead to differences in terms of bioactivities. Furthermore, the protein obtention process seems to play a role, since differences for some bioactivities could be observed between the four grades of pea protein (PeaP1, PeaP2, PeaP3, and PeaP4) before and after SGID.

Supplementary Materials: The following are available online at http://www.mdpi.com/2072-6643/12/12/3746/s1, Figure S1: Apparent molecular weight peptide profiles of PeaP1 at the end of the SGID intestinal step, obtained after SEC-FPLC, Figure S2: Apparent molecular weight peptide profiles of PeaP2 at the end of the SGID intestinal step, obtained after SEC-FPLC, Figure S3: Apparent molecular weight peptide profiles of PeaP3 at the end of the SGID intestinal step, obtained after SEC-FPLC, Figure S4: Apparent molecular weight peptide profiles of PeaP4 at the end of the SGID intestinal step, obtained after SEC-FPLC, Figure S5: Apparent molecular weight peptide profiles of HPeaP at the end of the SGID intestinal step, obtained after SEC-FPLC, Figure S6: Apparent molecular weight peptide profiles of WP1 at the end of the SGID intestinal step, obtained after SEC-FPLC, Figure S7: Apparent molecular weight peptide profiles of WP2 at the end of the SGID intestinal step, obtained after SEC-FPLC, Figure S8: Apparent molecular weight peptide profiles of PP at the end of the SGID intestinal step, obtained after SEC-FPLC, Figure S9: Apparent molecular weight peptide profiles of FBP at the end of the 
SGID intestinal step, obtained after SEC-FPLC, Figure S10: Apparent molecular weight peptide profiles of OP at the end of the SGID intestinal step, obtained after SEC-FPLC, Figure S11: Apparent molecular weight peptide profiles of WhP at the end of the SGID intestinal step, obtained after SEC-FPLC, Figure S12: Apparent molecular weight peptide profiles of Blank SGID at the end of the SGID intestinal step, obtained after SEC-FPLC.

Author Contributions: Conceptualization, B.C., C.L.-M., and R.R.; methodology, C.D., M.T., B.C., J.B.-M., and R.R.; formal analysis, C.D., B.C., J.B.-M., and R.R.; investigation, C.D. and M.T.; writing-original draft preparation, C.D.; writing-review and editing, B.C., J.B.-M., R.R., J.C., L.G.-D., C.L.-M.; supervision, B.C., C.L.-M., and R.R.; All authors have read and agreed to the published version of the manuscript.

Funding: This research received no external funding.

Acknowledgments: This work was supported by the Hauts-de-France region funding through the ALIBIOTECH research program.

Conflicts of Interest: Protein samples have been provided by Roquette. Catherine Lefranc-Millot, Laetitia Guérin-Deremaux, and Juliette Caron are employed by Roquette.

\section{References}

1. Lonnie, M.; Hooker, E.; Brunstrom, J.M.; Corfe, B.M.; Green, M.A.; Watson, A.W.; Williams, E.A.; Stevenson, E.J.; Penson, S.; Johnstone, A.M. Protein for Life: Review of Optimal Protein Intake, Sustainable Dietary Sources and the Effect on Appetite in Ageing Adults. Nutrients 2018, 10, 360. [CrossRef] [PubMed]

2. Pihlanto, A.; Mattila, P.; Mäkinen, S.; Pajari, A.-M. Bioactivities of alternative protein sources and their potential health benefits. Food Funct. 2017, 8, 3443-3458. [CrossRef] [PubMed]

3. González, A.D.; Frostell, B.; Carlsson-Kanyama, A. Protein efficiency per unit energy and per unit greenhouse gas emissions: Potential contribution of diet choices to climate change mitigation. Food Policy 2011, 36, 562-570. [CrossRef]

4. Lefranc-Millot, C.; Teichman-Dubois, V. Protein from Vegetable Sources: A Focus on Pea Protein. In Novel Proteins for Food, Pharmaceuticals and Agriculture; Hayes, D., Ed.; John Wiley \& Sons, Ltd.: Chichester, UK, 2018; pp. 197-216.

5. Rutherfurd-Markwick, K.J. Food proteins as a source of bioactive peptides with diverse functions. Br. J. Nutr. 2012, 108, S149-S157. [CrossRef]

6. Anderson, G.H.; Aziz, A. Multifunctional roles of dietary proteins in the regulation of metabolism and food intake: Application to feeding infants. J. Pediatr. 2006, 149, S74-S79. [CrossRef]

7. Chakrabarti, S.; Guha, S.; Majumder, K. Food-Derived Bioactive Peptides in Human Health: Challenges and Opportunities. Nutrients 2018, 10, 1738. [CrossRef]

8. Moughan, P.J.; Rutherfurd, S.M.; Montoya, C.A.; Dave, L.A. Food-derived bioactive peptides-A new paradigm. Nutr. Res. Rev. 2014, 27, 16-20. [CrossRef]

9. Manzanares, P.; Gandía, M.; Garrigues, S.; Marcos, J.F. Improving Health-Promoting Effects of Food-Derived Bioactive Peptides through Rational Design and Oral Delivery Strategies. Nutrients 2019, 11, 2545. [CrossRef]

10. Möller, N.P.; Scholz-Ahrens, K.E.; Roos, N.; Schrezenmeir, J. Bioactive peptides and proteins from foods: Indication for health effects. Eur. J. Nutr. 2008, 47, 171-182. [CrossRef]

11. Caron, J.; Domenger, D.; Dhulster, P.; Ravallec, R.; Cudennec, B. Protein Digestion-Derived Peptides and the Peripheral Regulation of Food Intake. Front. Endocrinol. 2017, 8, 85. [CrossRef]

12. Janssen, S.; Depoortere, I. Nutrient sensing in the gut: New roads to therapeutics? Trends Endocrinol. Metab. 2013, 24, 92-100. [CrossRef] [PubMed]

13. Rønnestad, I.; Akiba, Y.; Kaji, I.; Kaunitz, J.D. Duodenal luminal nutrient sensing. Curr. Opin. Pharmacol. 2014, 19, 67-75. [CrossRef] [PubMed]

14. Nadkarni, P.; Chepurny, O.G.; Holz, G.G. Regulation of Glucose Homeostasis by GLP-1. Prog. Mol. Biol. Transl. Sci. 2014, 121, 23-65. [CrossRef] [PubMed]

15. Juillerat-Jeanneret, L. Dipeptidyl Peptidase IV and Its Inhibitors: Therapeutics for Type 2 Diabetes and What Else? J. Med. Chem. 2014, 57, 2197-2212. [CrossRef]

16. Drucker, D.J.; Nauck, M.A. The incretin system: Glucagon-like peptide-1 receptor agonists and dipeptidyl peptidase-4 inhibitors in type 2 diabetes. Lancet 2006, 368, 1696-1705. [CrossRef]

17. Nongonierma, A.B.; FitzGerald, R.J. Features of dipeptidyl peptidase IV (DPP-IV) inhibitory peptides from dietary proteins. J. Food Biochem. 2019, 43, e12451. [CrossRef] 
18. Duraffourd, C.; De Vadder, F.; Goncalves, D.; Delaere, F.; Penhoat, A.; Brusset, B.; Rajas, F.; Chassard, D.; Duchampt, A.; Stefanutti, A.; et al. Mu-Opioid Receptors and Dietary Protein Stimulate a Gut-Brain Neural Circuitry Limiting Food Intake. Cell 2012, 150, 377-388. [CrossRef]

19. Mithieux, G.; Misery, P.; Magnan, C.; Pillot, B.; Gautier-Stein, A.; Bernard, C.; Rajas, F.; Zitoun, C. Portal sensing of intestinal gluconeogenesis is a mechanistic link in the diminution of food intake induced by diet protein. Cell Metab. 2005, 2, 321-329. [CrossRef]

20. Ganguly, A.; Sharma, K.; Majumder, K. Food-derived bioactive peptides and their role in ameliorating hypertension and associated cardiovascular diseases. Adv. Food Nutr. Res. 2019, 89, 165-207. [CrossRef]

21. Fernández-Tomé, S.; Hernández-Ledesma, B.; Chaparro, M.; Indiano-Romacho, P.; Bernardo, D.; Gisbert, J.P. Role of food proteins and bioactive peptides in inflammatory bowel disease. Trends Food Sci. Technol. 2019, 88, 194-206. [CrossRef]

22. Caron, J.; Cudennec, B.; Domenger, D.; Belguesmia, Y.; Flahaut, C.; Kouach, M.; Lesage, J.; Goossens, J.-F.; Dhulster, P.; Ravallec, R. Simulated GI digestion of dietary protein: Release of new bioactive peptides involved in gut hormone secretion. Food Res. Int. 2016, 89, 382-390. [CrossRef] [PubMed]

23. Lacroix, I.M.E.; Li-Chan, E.C.Y. Dipeptidyl peptidase-IV inhibitory activity of dairy protein hydrolysates. Int. Dairy J. 2012, 25, 97-102. [CrossRef]

24. Garreau, I.; Zhao, Q.; Pejoan, C.; Cupo, A.; Piot, J.M. VV-hemorphin-7 and LVV-hemorphin-7 released during in vitro peptic hemoglobin hydrolysis are morphinomimetic peptides. Neuropeptides 1995, 28, $243-250$. [CrossRef]

25. Sentandreu, M.A.; Toldrá, F. A fluorescence-based protocol for quantifying angiotensin-converting enzyme activity. Nat Protoc 2006, 1, 2423-2427. [CrossRef]

26. Aruoma, O.I.; Halliwell, B.; Hoey, B.M.; Butler, J. The antioxidant action of N-acetylcysteine: Its reaction with hydrogen peroxide, hydroxyl radical, superoxide, and hypochlorous acid. Free Radic. Biol. Med. 1989, 6, 593-597. [CrossRef]

27. Thurman, R.G.; Ley, H.G.; Scholz, R. Hepatic microsomal ethanol oxidation. Hydrogen peroxide formation and the role of catalase. Eur. J. Biochem. 1972, 25, 420-430. [CrossRef]

28. Halliwell, B.; Gutteridge, J.M.C.; Aruoma, O.I. The deoxyribose method: A simple "test-tube" assay for determination of rate constants for reactions of hydroxyl radicals. Anal. Biochem. 1987, 165, 215-219. [CrossRef]

29. Giromini, C.; Cheli, F.; Rebucci, R.; Baldi, A. Invited review: Dairy proteins and bioactive peptides: Modeling digestion and the intestinal barrier. J. Dairy Sci. 2019, 102, 929-942. [CrossRef]

30. Park, Y.W.; Nam, M.S. Bioactive Peptides in Milk and Dairy Products: A Review. Korean J. Food Sci. Anim. Resour. 2015, 35, 831-840. [CrossRef]

31. Santos-Hernández, M.; Tomé, D.; Gaudichon, C.; Recio, I. Stimulation of CCK and GLP-1 secretion and expression in STC-1 cells by human jejunal contents and in vitro gastrointestinal digests from casein and whey proteins. Food Funct. 2018, 9, 4702-4713. [CrossRef]

32. Geraedts, M.C.P.; Troost, F.J.; Fischer, M.A.J.G.; Edens, L.; Saris, W.H.M. Direct induction of CCK and GLP-1 release from murine endocrine cells by intact dietary proteins. Mol. Nutr. Food Res. 2011, 55, 476-484. [CrossRef] [PubMed]

33. Power-Grant, O.; Bruen, C.; Brennan, L.; Giblin, L.; Jakeman, P.; FitzGerald, R.J. In vitro bioactive properties of intact and enzymatically hydrolysed whey protein: Targeting the enteroinsular axis. Food Funct. 2015, 6, 972-980. [CrossRef] [PubMed]

34. Cudennec, B.; Ravallec-Plé, R.; Courois, E.; Fouchereau-Peron, M. Peptides from fish and crustacean by-products hydrolysates stimulate cholecystokinin release in STC-1 cells. Food Chem. 2008, 111, 970-975. [CrossRef]

35. Cudennec, B.; Fouchereau-Peron, M.; Ferry, F.; Duclos, E.; Ravallec, R. In Vitro and in vivo evidence for a satiating effect of fish protein hydrolysate obtained from blue whiting (Micromesistius poutassou) muscle. J. Funct. Foods 2012, 4, 271-277. [CrossRef]

36. Sufian, K.N.B.; Hira, T.; Nakamori, T.; Furuta, H.; Asano, K.; Hara, H. Soybean $\beta$-Conglycinin Bromelain Hydrolysate Stimulates Cholecystokinin Secretion by Enteroendocrine STC-1 Cells to Suppress the Appetite of Rats under Meal-Feeding Conditions. Biosci. Biotechnol. Biochem. 2011, 75, 848-853. [CrossRef] 
37. Foltz, M.; Ansems, P.; Schwarz, J.; Tasker, M.C.; Lourbakos, A.; Gerhardt, C.C. Protein Hydrolysates Induce CCK Release from Enteroendocrine Cells and Act as Partial Agonists of the CCK-1-Receptor. J. Agric. Food Chem. 2008, 56, 837-843. [CrossRef]

38. Geraedts, M.C.P.; Troost, F.J.; Tinnemans, R.; Söderholm, J.D.; Brummer, R.-J.; Saris, W.H.M. Release of Satiety Hormones in Response to Specific Dietary Proteins Is Different between Human and Murine Small Intestinal Mucosa. Ann Nutr Metab 2010, 56, 308-313. [CrossRef]

39. Chen, W.; Hira, T.; Nakajima, S.; Hara, H. Wheat gluten hydrolysate potently stimulates peptide-YY secretion and suppresses food intake in rats. Biosci. Biotechnol. Biochem. 2018, 82, 1992-1999. [CrossRef]

40. Caron, J.; Domenger, D.; Dhulster, P.; Ravallec, R.; Cudennec, B. Using Caco-2 cells as novel identification tool for food-derived DPP-IV inhibitors. Food Res. Int. 2017, 92, 113-118. [CrossRef]

41. Nongonierma, A.B.; Lalmahomed, M.; Paolella, S.; FitzGerald, R.J. Milk protein isolate (MPI) as a source of dipeptidyl peptidase IV (DPP-IV) inhibitory peptides. Food Chem. 2017, 231, 202-211. [CrossRef]

42. Nongonierma, A.B.; FitzGerald, R.J. Investigation of the Potential of Hemp, Pea, Rice and Soy Protein Hydrolysates as a Source of Dipeptidyl Peptidase IV (DPP-IV) Inhibitory Peptides. Food Dig. Res. Curr. Opin. 2015, 6, 19-29.

43. Wang, F.; Yu, G.; Zhang, Y.; Zhang, B.; Fan, J. Dipeptidyl Peptidase IV Inhibitory Peptides Derived from Oat (Avena sativa L.), Buckwheat (Fagopyrum esculentum), and Highland Barley (Hordeum vulgare trifurcatum (L.) Trofim) Proteins. J. Agric. Food Chem. 2015, 63, 9543-9549. [CrossRef] [PubMed]

44. Liu, Z.; Udenigwe, C.C. Role of food-derived opioid peptides in the central nervous and gastrointestinal systems. J. Food Biochem. 2019, 43, e12629. [CrossRef] [PubMed]

45. Domenger, D.; Cudennec, B.; Kouach, M.; Touche, V.; Landry, C.; Lesage, J.; Gosselet, F.; Lestavel, S.; Goossens, J.-F.; Dhulster, P.; et al. Food-Derived Hemorphins Cross Intestinal and Blood-Brain Barriers In Vitro. Front. Endocrinol. 2018, 9. [CrossRef]

46. Kim, S.-K.; Ngo, D.-H.; Vo, T.-S. Marine Fish-Derived Bioactive Peptides as Potential Antihypertensive Agents. Adv. Food Nutr. Res. 2012, 65, 249-260. [CrossRef]

47. Sánchez, A.; Vázquez, A. Bioactive peptides: A review. Food Qual. Safet. 2017, 1, 29-46. [CrossRef]

48. Manoharan, S.; Shuib, A.S.; Abdullah, N. Structural Characteristics and Antihypertensive Effects of Angiotensin-I-Converting Enzyme Inhibitory Peptides in THE Renin-Angiotensin and Kallikrein Kinin Systems. Afr. J. Tradit. Complement. Altern. Med. 2017, 14, 383-406. [CrossRef]

49. Boschin, G.; Scigliuolo, G.M.; Resta, D.; Arnoldi, A. ACE-inhibitory activity of enzymatic protein hydrolysates from lupin and other legumes. Food Chem. 2014, 145, 34-40. [CrossRef]

50. Rudolph, S.; Lunow, D.; Kaiser, S.; Henle, T. Identification and quantification of ACE-inhibiting peptides in enzymatic hydrolysates of plant proteins. Food Chem. 2017, 224, 19-25. [CrossRef]

51. Guha, S.; Majumder, K. Structural-features of food-derived bioactive peptides with anti-inflammatory activity: A brief review. J. Food Biochem. 2019, 43, e12531. [CrossRef]

52. Zhang, H.; Kovacs-Nolan, J.; Kodera, T.; Eto, Y.; Mine, Y. $\gamma$-Glutamyl cysteine and $\gamma$-glutamyl valine inhibit TNF- $\alpha$ signaling in intestinal epithelial cells and reduce inflammation in a mouse model of colitis via allosteric activation of the calcium-sensing receptor. Biochim. Biophys. Acta 2015, 1852, 792-804. [CrossRef] [PubMed]

53. Van De Walle, J.; Hendrickx, A.; Romier, B.; Larondelle, Y.; Schneider, Y.-J. Inflammatory parameters in Caco-2 cells: Effect of stimuli nature, concentration, combination and cell differentiation. Toxicol. In Vitro 2010, 24, 1441-1449. [CrossRef] [PubMed]

54. Nwachukwu, I.D.; Aluko, R.E. Structural and functional properties of food protein-derived antioxidant peptides. J. Food Biochem. 2019, 43, e12761. [CrossRef] [PubMed]

Publisher's Note: MDPI stays neutral with regard to jurisdictional claims in published maps and institutional affiliations. 